University of South Florida

DIGITAL COMMONS

Digital Commons @ University of

@ UNIVERSITY OF SOUTH FLORIDA

South Florida

KIP Monographs

KIP Research Publications

January 2009

\title{
The ancient Maya drought cult: Late classic cave use in Belize
}

Jaime J. Awe

George A. Brook

Holley Moyes

James w. Webster

Follow this and additional works at: https://digitalcommons.usf.edu/kip_monographs

\section{Recommended Citation}

Awe, Jaime J.; Brook, George A.; Moyes, Holley; and Webster, James w., "The ancient Maya drought cult: Late classic cave use in Belize" (2009). KIP Monographs. 5.

https://digitalcommons.usf.edu/kip_monographs/5

This Book is brought to you for free and open access by the KIP Research Publications at Digital Commons @ University of South Florida. It has been accepted for inclusion in KIP Monographs by an authorized administrator of Digital Commons @ University of South Florida. For more information, please contact digitalcommons@usf.edu. 


\title{
THE ANCIENT MAYA DROUGHT CULT: LATE CLASSIC CAVE USE IN BELIZE
}

\author{
Holley Moyes, Jaime J. Awe, George A. Brook, and James W. Webster
}

\begin{abstract}
Caves were used as ritual venues by the ancient Maya from the Early Preclassic to the Postclassic period. These sites have been intensively investigated, but little research has been devoted to changes in cave use over time. Work at Chechem Ha Cave in western Belize investigates transformations in ritual practice occurring between the Early and Late Classic periods using an explanatory framework that incorporates high-definition archaeological research with a paleoclimate reconstruction derived from speleothems. This is one of the first projects to directly link these data to the archaeological record. We also introduce new methodology to evaluate changes in ritual practice using use-intensity proxies and artifact patterning. These data demonstrate that Late Classic transformations were coeval with climatic drying. The phenomenon was identified in this case study, and the pattern is prevalent throughout the eastern lowlands suggesting that an ancient Maya drought cult was initiated at this time. We provide the first evidence that there was a failed ritual response to environmental stress, implying that a loss of faith in Maya rulership contributed to the downfall of political systems. This is an important finding for collapse theories that include ideological causations.
\end{abstract}

Las cuevas fueron utilizadas por los antiguos mayas como lugares rituales desde el Preclásico Temprano Medio hasta Postclásico. Si bien han sido intensamente investigadas, poco se ha hecho para entender los cambios temporales en el uso de las cuevas. Las investigaciones en Chechem Ha, una cueva ubicada Belice occidental, aportan al conocimiento sobre las transformaciones en la práctica ritual entre los periodos Clásicos Temprano y Final a través de la investigación arqueológica de alta definición conjuntamente con la reconstrucción paleoclimática derivada de estalagmitas; siendo este uno de los primeros proyectos que realiza este intento. También introducimos una nueva metodología para evaluar los cambios en la práctica ritual empleando proxies de uso intensivo y patrones en los artefactos. Estos datos demuestran que las transformaciones del Clásico Final covarían con el proceso de desertización climático. Esto fue identificado en este caso y el patrón es frecuente a través de las tierras bajas orientales sugiriendo que el antiguo culto maya de la sequía comenzó durante esos momentos. Proporcionamos la primera evidencia de una respuesta ritual fallida al estrés ambiental, dando lugar a una pérdida de fe en las reglas y liderazgos mayas contribuyendo así a la caída de los sistemas políticos. Este es un dato importante dentro de las teorías del colapso maya ya que tienen en cuenta las causalidades ideológicas de la población.

$\mathrm{N}$ umerous recent paleoenvironmental studies have demonstrated that a dry period or drought was coincident with the ninthcentury A.D. Classic Maya collapse. These studies have utilized data sources such as lake cores from the Peten and Yucatán (Brenner et al. 2002; Curtis et al. 1996; Curtis et al. 1998; Dunning et al. 1997; Hodell et al. 1995; Hodell et al. 2001; Rosenmeier et al. 2002) as well as the highresolution sediments from the Cariaco Basin in Venezuela (Haug et al. 2003; Peterson and Haug 2005). Richardson Gill (2000) argued mightily that drought was the driving force behind the collapse, the Preclassic abandonment, and Maya hiatus. While the latter are still debated, it is difficult to disassociate regional drought from the Classic collapse due to the overwhelming cumulative scientific evidence derived from numerous regional studies.

Agency theories remind us that it is not the event per se but the human response to it that causes changes in the social order or "collapse." Recent studies (Aimers 2007; Demarest et al. 2004:546) question the usage of terms such as collapse or fall

Holley Moyes • Department of Anthropology, University of Arizona, Tucson, AZ 85745 (hmoyes@email.arizona.edu)

Jaime J. Awe Director, Belize Institute of Archaeology, Belmopan, Belize (jaimeawe@yahoo.com)

George A. Brook - Department of Geography, University of Georgia, Athens, GA 30602 (gabrook@uga.edu)

James W. Webster - U.S. Environmental Protection Agency, Atlanta, GA 30303 
because they are colorful but misleading. Demarest and his colleagues suggest that the events of the late ninth century primarily represent changing political systems and ideology. In other words, instead of representing the total failure of an entire civilization, the "collapse" has been redefined as the decline of the elite institutions and the abandonment of the kingship in the Maya Lowlands.

It is well recognized that explanations for the collapse are complex issues. Thus, archaeologists have introduced systemlike explanations to model the integration between internal and external factors that contributed to the ultimate decline of political institutions (Demarest et al. 2004:565; Hosler et al. 1977; Lowe 1985; Renfrew 1978; Webster 2002:328-329; Willey and Shimkin 1971, 1973). Ideological factors play a role_-at times a central role_-in many of these models. For instance, years ago J. Eric Thompson (1954:266-269) proposed that the collapse resulted from alienation between the elite and peasantry that led to a peasant revolt. In Thompson's model, the peasants rejected the elite ideology of warfare and gods of war. Malcolm Webb (1973:389) thought that Maya cities were cult centers that would have no reason to exist without the cult and would be subject to collapse if any set of circumstances successfully challenged the belief system. He argued that if theocratic rulers met crises by devoting shrinking resources to cultic ends that produced no improvement of conditions, (such as monument construction and stela erection during the Late Classic period), elite credibility would suffer, causing the collapse of the cult. Dennis Puleston (1979) suggested that elite ideology had a limitation on its duration based on cyclical time. He suggested that the co-occurrence of unusual stress on the political system with the end of the 13-katun (256-year) temporal cycle became a self-validating myth that produced a general sense of fatalism among the Maya. This is echoed in Prudence Rice's (2004) research also suggesting that Maya political systems were regulated by cyclical time. The 256-year may cycles may have structured history by transferring cosmological power within a given region from one site to another.

Later versions of the role of ideology in collapse models take an agent-based approach arguing that the loss of faith in the state ideology and religion was a major component if not the major cause of the fall of kingships. Jane Lopiparo (2001:49) argued that "ideological currency" was the only commodity that elites had to offer commoners. She explained the collapse by invoking Gramsci's concept of "ideological consent" (Salamini 1981:33), which states that changes in political systems occur first in the minds of the masses, a notion proposed for the origins of kingship by David Freidel (1981).

David Webster has argued that internal and external stresses led to an ideological resistance that caused the decline of the royal institutions. In his model, as social conditions deteriorated, both commoners and lesser elites could point to the kings as scapegoats (2002:329, 343-347). In her study of Maya art, Mary Ellen Miller concludes that by the end of the Late Classic period "the disjunction between what was known of the cosmos and what was happening may have been so profound that faith ebbed among the Maya" (1993:410). Similarly, in her studies of ritual activities over time, Lisa Lucero $(2002,2006)$ argued that the populace lost faith in rulers who were then unable to exact tribute, which in turn caused the downfall of royal institutions.

Inherent in all of these theories is an implicit assumption or explicit acceptance that a hardship affected the general Maya population in the Late Classic period. Recent climate studies suggest that this hardship took the form of climatic stress resulting in a drop in agricultural production. What is lacking is archaeological evidence to suggest that a loss of faith in the rulership accompanied these events. Studies of ritual can provide such evidence by demonstrating a failed ritual response. Without these data, arguments that include ideological components in collapse theories remain ungrounded.

In this article we will demonstrate that there was such a response. Our study evaluates detailed local paleoenvironmental data and fine-grained archaeological investigations to demonstrate that there was a change in ritual practice in the Late Classic period coeval with the beginning of a prolonged period of climatic drying. This archaeological phenomenon was first noted in investigations conducted at Chechem Ha Cave (Actun Chechem Ha) by Holley Moyes with the Western Belize Regional Cave Project (WBRCP) under the direction of Jaime J. Awe.

One of the major contributions of the study is that we were able to identify changes in ritual practice over time by evaluating the use of space, the 
nature of the artifact assemblage, and the ritual useintensity of the site (Moyes 2004, 2006a, 2007, 2008). Ritual use-intensity is a new method developed for the study that evaluates the frequency of, length of, or number of participants involved in ritual performance over time by quantifying and analyzing material remains. Once defined, ritual transformations are contextualized within sociopolitical and environmental frameworks.

Concurrent paleoenvironmental work based on speleothem data collected by James Webster (2000) from the nearby Macal Chasm cave provides the paleoclimate record for the study. These are the first speleothem data for Mesoamerica, and they are compelling for two reasons. First, speleothems provide a fine-grained paleoclimate record at a scale that can be correlated with the archaeological record, and second, the data infer local precipitation levels from a nearby source. This reduces possible discrepancies concerning microenvironments.

Although this article focuses on ritual transformations that occurred at Chechem $\mathrm{Ha}$ Cave between the Early (A.D. 250-600) and Late (A.D. 600-900) Classic periods, these are not isolated phenomena. Distinct patterns of cave use during the Late Classic period can be observed in almost every known cave site in Belize. We argue that these ritual transformations, which are coeval with deteriorating climatic conditions, are the manifestation of a Late Classic drought cult.

\section{The Nature of Cave Use}

Since the 1970 s there has been a steadily increasing number of archaeological, iconographic, and epigraphic studies of ancient Mesoamerican cave sites and their cultural representations (Brady and Prufer 2005). The most important collective finding of these studies is the establishment of caves as sacred space and their use as ritual venues by precolumbian people. Another major finding is that throughout Mesoamerica, they are part of an ideological nexus of mountains, caves, and water. This ideology links caves with the sacred earth, which is considered to be the primordial source of all abundance and fertility in Mesoamerican thought (Brady 1989; Brady and Ashmore 1999; Brady and Prufer 2005; Moyes and Brady 2005).

Although ancient cave sites were highly politi- cized spaces that functioned as multipurpose ritual venues during the Classic period (see e.g., Brady 1989; Brady and Colas 2005; Colas 1998; Moyes 2005a; Stone 1995, 2005), it was likely due to the ideological connections between caves and water control — and by extension, agricultural fertility. This can be demonstrated from deep antiquity in the iconography from the Olmec civilization (1200-200 B.C.). The water/fertility theme is illustrated in the El Rey monument from Chalcatzingo (Figure 1). In the image a ruler or ancestor sits on a cloud scroll within a cave that emanates mist or smoke from the entrance. Clouds rain on the scene, and corn and other vegetation are depicted on the surface over the cave (Grove and Gillespie 1984:3233; Reilly 1994:78-79).

The water/fertility theme is pervasive throughout Mesoamerica and is found much later in the Preclassic Maya murals from San Bartolo that date to the first century B.C. The mural on the north wall illustrates a creation event in which maize tamales and a gourd of water are being handed out of the entrance of a cave, probably a cave of origin (Saturno et al. 2005). An early representation of the ancient Maya Maize God is depicted standing at the mouth of the cave accepting the offerings. The association suggests that both the first maize and primordial water issued from caves, and explains their importance in later water and fertility rites.

The archaeological record suggests that in the Classic period many cave rites were water-related. This is not surprising when we consider that a number of deities thought to reside in caves were associated with agricultural success. For instance, the Maya rain god Chac is depicted sitting in his cave/house on a Classic period vase (Coe 1978:78n11). A reified example of this is found at the cave of La Pailita in Guatemala where a lifesized sculpture of Chac sits on his throne in the cave's interior (Graham 1997).

Activity areas in caves also suggest that water was an important feature of cave rites. The formal spatial analysis conducted by the WBRCP in the Main Chamber of Actun Tunichil Muknal (Cave of the Crystal Sepulcher) found that 51 percent of the artifact assemblage was placed in intermittent pools (Moyes 2001; Moyes and Awe 1998, 2000). In his survey of 48 caves in the Yalahau area of Quintana Roo, Dominique Rissolo (2001, 2005) found that many caves contained interior water fea- 


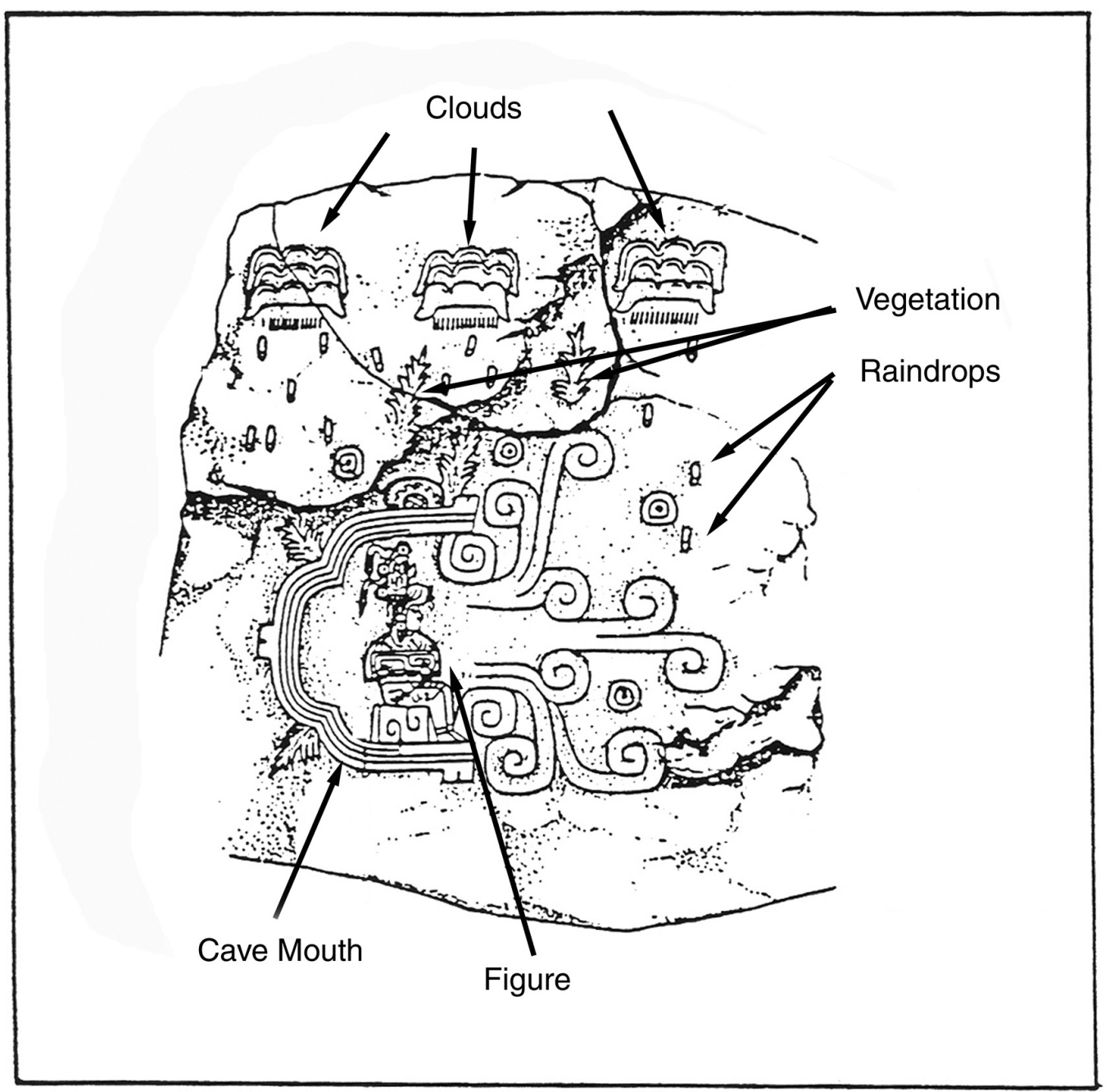

Figure 1. El Rey monument is a bas relief illustrating an important person sitting within a cave. Clouds rain on top of the cave and plants are shown growing on the surface (after Reilly 1994:85).

tures. He noted that both rock art and architectural modifications tended to be associated with these features and art from the cave of Pak Che'n contained rain god motifs.

At the cave of Balankanche in Yucatán large anthropomorphic censers were scattered around a stalagmitic column (Andrews 1970:69). Most of the censers were modeled with images of the central Mexican rain god Tlaloc. Similarly, at the site of the Gruta de Chac, Andrews (1965:14) reported finding a large number of painted globular jars with water motifs of stylized frogs and waterbirds. These were located throughout a passage that led to an underground pool. Because of the motifs on the jars and their spatial proximity to the underground water source, Michael Smyth (1998) later argued that they were offerings to rain deities.

\section{Jars as the Possessions of Rain Deities}

Cave research conducted by the WBRCP in western Belize found that ceramic jars and jar sherds are some of the most common artifacts deposited within cave sites. This is not a local phenomenon, and the ubiquitous presence of jars has been widely reported (e.g., Brady 1989; Rissolo 2001; Smyth 1998; Woodfill 2007). Ethnographically, jars are divided into three functional groups: narrow-mouth jars for carrying water, wide-mouth jars for storage, and those with wide collars and low necks 
used for cooking (Reina and Hill 1978:26; Thompson 1958:121-123). Smaller varieties are used as water bottles around the house. Wide-mouthed jars may be used for storing water, maize seed, and a variety of other things or may be used for making balche, an alcoholic beverage brewed from maize. However, large jars not only are functional but also have cosmological connotations associated with rain deities.

Ethnographic evidence reported by Tarn and Prechtel (1986:176) from Lake Atitlan in Guatemala points out that Maria Castellana, a female creatrix, is directly associated with the moon. The moon is thought to hold rainwater and is envisioned as a large jar. Over the rainy season the crest of the moon/jar is seen to turn sideways, spilling out water, symbolizing the deity pouring water from her celestial olla. Raphael Girard (1995:162-167) describes a similar belief that among the Chortí that is reenacted when female senior elders pour water from jars onto the ground during rain rites.

These notions likely derive from a long-standing prehispanic tradition. Based on his systematic study of water motifs in ancient Mesoamerican art, Robert Rands (1955:344) noted that the existence of the belief that rain was poured from a container was "clear and unmistakable" throughout the entire region. He found that water poured from containers was the most common iconographic motif used to symbolize rain.

In the Dresden Codex there is an illustration of the primordial flood that Karl Taube (1992:100, 1995:69-71) has associated with the original Maya creation event (Figure 2). An old woman named in the codex as Chac Chel and identified as Goddess $\mathrm{O}$, the Moon Goddess, hangs in the sky. In her hands is an inverted jar spilling water. A similar depiction of the goddess can be found on page $43 \mathrm{~b}$. In the Madrid Codex flood pages she is seen in a similar stance on pages $10 \mathrm{~b}$ and $29 \mathrm{~b}$. Also, on page 30a of the Madrid, both she and Chac the rain deity are illustrated pouring water from inverted jars. James Brady (1989:47-49) has long argued that this female deity is associated with caves because she is pictured in the cave paintings at Naj Tunich and is often associated with the cave-dwelling rain god Chac.

Evidence for the ritual association of jars as offerings to rain deities is also found among the
Aztecs, who offered globular jars to the rain god Tlaloc (Luján 1998:180). At the Templo Mayor, jars associated with large bowls were found in six dedicatory caches (Zantwijk 1981). The jars contained greenstone beads and were positioned on their sides with the bowls beneath their mouths. Both Seler (1991, 2:281 [1902-1923]) and Krickeberg $(1975: 152)$ have suggested that beads may represent droplets of precious water.

Based on a Mexica myth in the Historia de los Mexicano por sus Pinturas (Phillips 1884:618, 638), Leonardo Luján (1998:180) argues that this cache configuration represented the celestial pouring of water from the sky by Tlaloc. In the myth, Tlaloc lives in a four-room chamber with tubs of water in each room. He orders his assistants to take up clubs and gather water from the tubs in vessels to scatter on the ground. When it thunders the assistants are thought to be breaking the vessels with their clubs.

In sixteenth-century documents, the Temple of Tlaloc is depicted with jars sitting atop the parapets (Códice Ramírez 1944: Plate 19; Durán 1971: Plate 30 [1588]). Also, in the Aztec principal festival dedicated to the god, a jar referred to as a "cloud jar" was covered with blue pigment and rubber. It was used as a container to transport the hearts of sacrificial Tlaloc impersonators to the middle of the lake where they were deposited as offerings to the water (Sahagun 1981:88).

\section{Climate and Cave Use}

One must ask why water rites were so important to the ancient Maya, who were known for their sophisticated water management techniques (Dunning et al. 1997; Marcus 2006; Scarborough 2003). The problem is that if there is no water, there is no water management; and in the tropics water sources can dry up quickly. The nature of extensive farming techniques, dispersal of farms across the landscape away from rivers or tributaries, and the lack of irrigation technologies contributed to the dependence on rain for agricultural production. According to the U.N. Land and Water Development Division (2007), in Belize today, there are no local farmers and few commercial farms that practice irrigation. This suggests that seasonal rainfall is still considered to be a reliable resource. Because of this general perception of reliability, it is not surprising that 


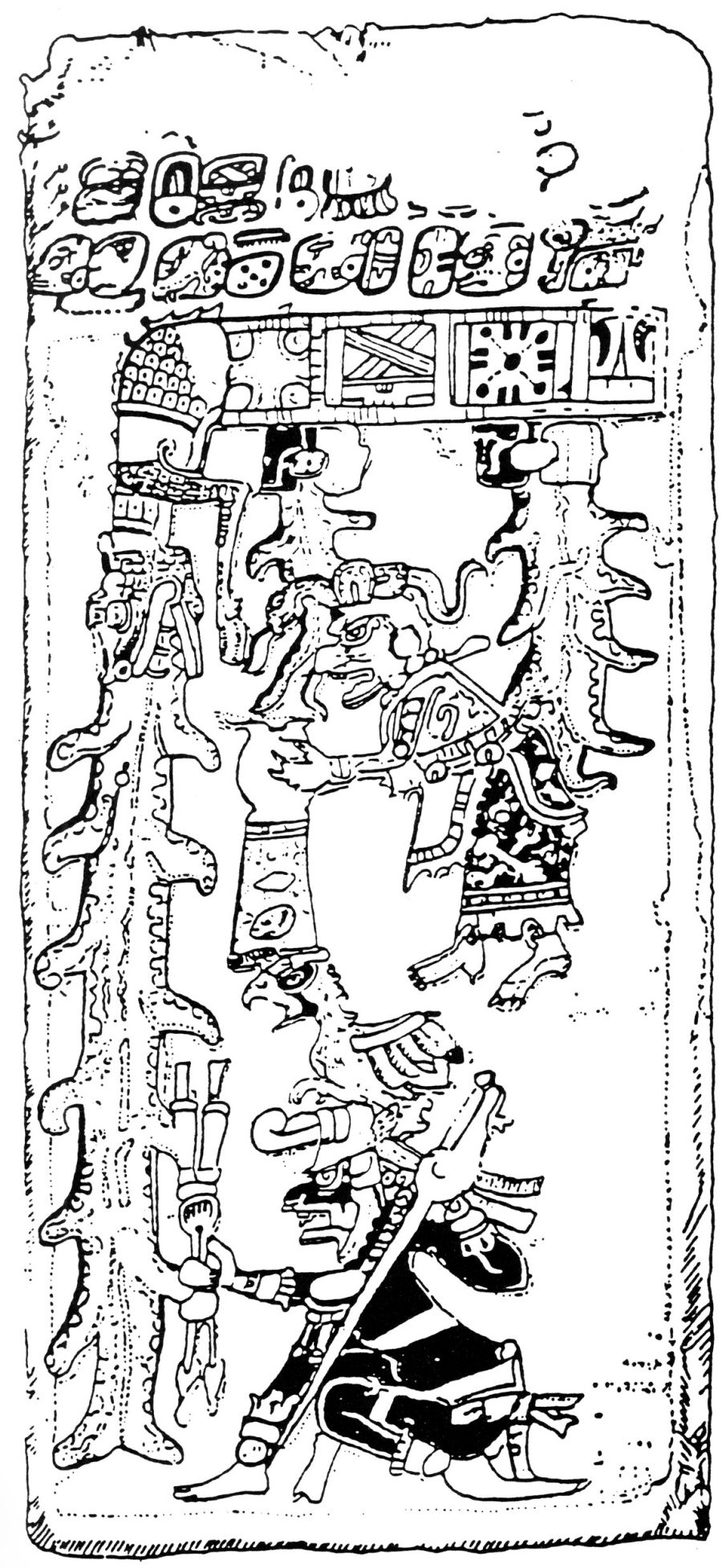

Figure 2. Page 74 of the Dresden Codex illustrates the Moon Goddess hanging in the sky and Chac the rain deity is positioned below (Villacorta 1992; Courtesy of Aegean Park Press). In her hands is a large jar from which she pours water. Taube (1992:100; 1995:71) has identified this scene as the primordial flood event. 
among the ancient Maya, ritual served as a largely successful technology to ensure rain (see Scarborough 1998).

Cross-culturally anthropologists note that in times of crises and stress one would expect groups to respond by increasing ritual activity as an effort to seek divine intervention (for instance, see Malinowski 1954:49-52; Van Gennep 1960). Ritual theorist Pierre Smith (1982) characterizes ritual in terms of "periodic" or "occasional" rites. Periodic rites consist of rituals or groups of rituals that occur cyclically, whereas occasional rites occur as needed, increasing ritual frequency. These rituals also referred to as rites of intensification, are often initiated to address conditions such as environmental crises, epidemics, or war events (Haviland et al. 2005:353). Among the Maya, ritual frequency is known to increase in times of stress, as noted ethnographically among the Chorti by Girard (1995:184). During a period of drought he witnessed a village shaman/priest conducting ongoing water rites to the point that the entire temple was flooded with water from the rituals.

Occasional rites are also known to be conducted in caves. Gary Gossen (1999:185) pointed out that today among the Tzotzil, rites in caves occur during times of duress such as drought or conflict. June Nash (1970:45) has similarly reported that ritual specialists held rites in caves to ask for rain in times of drought in Chiapas. Alan Sandstrom (2005) writes that as recently as 1998 , a ritual specialist organized an elaborate cave pilgrimage with a combined group of Nahua and Otomí people from northern Veracruz, Mexico, to appeal for rain during a catastrophic drought.

The use of ritual as a technology to anticipate and minimize agricultural risk has been demonstrated among modern Maya groups by David Freidel and Justine Shaw (2000). Based on 43 ethnographic and ethnohistoric cases, they reported that in areas where agriculture was risky, primarily due to water availability, ritual increased. Additionally, in areas of high risk, farmers emphasized rituals concerning crop maintenance and harvest, whereas in more stable areas rituals emphasized planting and field preparation. What this implies is that water availability is one of the primary concerns of modern Maya agriculturists and that ritual investment is somewhat linked to agricultural risk based on environmental factors.
This suggests that in times of drought one would expect to find evidence of maintenance and harvest rites such as first fruit ceremonies. While planting and field-preparation rites are traditionally conducted in fields, first fruit rites may have a long tradition of being conducted in caves because of their ideological associations with the first maize and primordial water. In practice, these rites may be recognized in the archaeological record by the presence of immature maize or fruit preserved in the cave environment (see Morehart 2005).

Because cave rites are strongly associated with agricultural success entailing the control of rainfall, we might reasonably expect them to be affected by climatic factors. Periodic rites should produce a constant archaeological signature. Disruption of these rites could be an indication of social disruption such as war, the spread of disease, or change in rulership. Climatic stress would be expected to produce an increase of occasional rites that could include existing ritual types or the introduction of new ritual forms. Occasional rites conducted over long periods should manifest as intensification in the archaeological record, and new forms of ritual practice based on changing circumstances may become institutionalized.

Archaeologists tend to assume that population density is a major contributor to the variation of ceramic counts in caves, but Moyes's study suggests that changes in ritual practice are far more apt to affect cave use proxies. The data from Chechem Ha Cave (Moyes 2006a:546, 586-587, Figures 8.1-8.2) clearly demonstrates that correlations between settlement data and cave use are only roughly correlated at best and do not have a 1:1 relationship.

Using cave data, it may be possible ascertain if people were inhabiting an area at a particular time using presence/absence determinations (Rissolo 2005), but there are problems in correlating population density with cave use. For instance, there is no evidence, ceramic or otherwise, to suggest that Chechem Has was used in the Postclassic period, though surface surveys indicate that there were small occupations in the region (Aimers 2004:67; Ashmore et al. 1994:283; Jones et al. 1986; Robin et al. 2004:45). Other studies that have addressed this issue found discrepancies as well. For instance, in his regional study of caves in the highlands near Cancuen, Brent Woodfill (2007:9) observed incon- 
gruities between population increase and cave use in the Late Classic period.

\section{A Behavioral Approach}

Typically archaeological cave studies have taken a synchronic approach to understanding ancient cave use. This is primarily because ethnographic analogy has served as the foremost interpretive paradigm (Brady 1989; Brady and Prufer 2005). This approach may be credited with major contributions to cave studies but its widespread use has also masked temporal changes in the way that caves were used and how cave practices may have changed. Although cave rites may have always been integrally linked to earth and rain deities associated with agricultural fertility and water control, we would still expect to see changes in ritual form and intensity over time. We also expect these ritual transformations to be linked to changing social or environmental conditions.

To better address changes and continuities in ritual practices one must turn to other approaches. In this case practice theory provides a good theoretical framework. Sherry Ortner has characterized the study of practice not just as a methodology to locate the point of view of agents but as one that seeks to understand "the configuration of cultural forms, social relations, and historical processes that move people to act in ways that produce the effects in question" (1989:12). It is not surprising that Ortner advocates a historical overview and considers the historical perspective vital to such studies. This suggests that despite limitations of their data, archaeologists are in a unique position to evaluate ritual transformations over considerable time scales. But, most methods employed by anthropologists are not effective for archaeological research.

Behavioral archaeology provides an archaeological approach for studying ritual change using material correlates. This school of thought initially advanced by Jefferson Reid, Michael Schiffer, and William Rathje seeks to explain variability and change in human behavior by emphasizing the study of relationships between people and their artifacts (Reid et al. 1975; Schiffer 1995, 1996, 1999). It shifts research efforts away from the interpretation of the meaning of artifacts to questions aimed at understanding the behaviors that created the site's depositional patterns.
William Walker (1995) has been instrumental in adapting a behavioral approach to the archaeology of ritual. Walker has pointed out that anthropology has traditionally conflated ritual studies with studies of belief systems. He contends that approaches to the study of religion should focus on the ritual behaviors that produced the artifact record rather than the attempt to interpret meaning from artifacts. It is the behavior or change in behavior that becomes the unit of analysis to be articulated with social processes and environmental circumstances. Therefore, understanding the behavior that produced the record is the most important step toward understanding archaeological phenomena.

\section{Ritual Intensity}

In terms of cave studies, the shift to a behavioral perspective requires new lines of inquiry that place emphasis on how and when a site was used rather than on the meaning of caves and their artifacts. At Chechem Ha, changes in ritual behavior are identified by evaluating variation in the use of space, analyzing the condition and provenience of artifacts, and by assessing ritual use-intensity. Useintensity is closely related to "ritual density" studies conducted by anthropologists. According to Catherine Bell (1997:173-209), these studies examine why some societies or historical periods have more ritual than others. She noted that density is rarely studied directly and lamented that there has been too little research of this type.

Ritual density can be difficult for ethnographers to address for two reasons. First, many traditional ethnographic studies have limited temporal frameworks and diachronic research necessitates historical perspectives to evaluate changes. The other difficulty is that the quantification of "density" is problematic. Studies have relied heavily on ritual typologies in order to quantify the types of rituals within a society so that studies of density are often typological exercises. Use-intensity addresses both of these issues by examining variability of the amount of ritual activity occurring over time. It is effective because it addresses ritual behavior directly and offers a broad perspective over long temporal periods.

The repetitiveness of ritual and the fact that it must be repeated in prescribed ways (Marcus and Flannery 1994:56; Rappaport 1979:176; Vogt 
1965:602-603; Whitehouse 2004) suggest that material correlates will remain the same until there is a change in practice. Therefore, ritual useintensity may be studied by identifying a material signature that correlates with an activity. There are two types of signatures to be considered-direct and indirect. Direct signatures are material manifestations that are part of the ritual itself. Indirect signatures are associated with the ritual actions but are not part of the ritual. Ritual intensity and changes in behavior may be best understood by studying a combination of the two types.

\section{Use-Intensity Proxies}

Use-intensity at Chechem Ha was addressed using two proxies - ceramics and charcoal flecks. Ceramics are considered to be a direct proxy. Whole or partial vessels as well as sherds were either deposited in the cave as offerings or were used in rites and abandoned as ritual trash. Charcoal is an indirect proxy because torch bearing was necessary for conducting rites within the dark zone. Archaeology, iconography, and ethnography all demonstrate that the Maya used wood torches to light their way in caves (Morehart 2005; Morehart et al. 2005; Moyes 2006a, 2006b, 2007, 2008; Prufer 2002), and evidence from the archaeological record strongly suggests that this was the sole source of fuel used in cave ritual. Charcoal flecks from torches are found in every utilized cave dark zone in Mesoamerica, and unburned wood fragments have been reported from a number of sites (Brady 1989:289-290; Gann 1925:111; Graham et al. 1980:169; Prufer 2002:614; Stone 1995:202). A partially burned torch fragment was located at Chechem Ha on Ledge 10, and charcoal flecks were present throughout the site. In his study of plant remains within the cave, Morehart (2002) reported that all charcoal flecks collected from surface deposits were of the Pinus species. Experiments conducted with ocote pine torches collected from the forest around the cave illustrated that they produced a steady rain of charcoal flecks that could be used as a proxy to evaluate fluctuations in activity occurring in the cave over time. Particular wood types may have been chosen for their ideological connotations, but this does not negate their function as torches (see Morehart et al. 2005). Charcoal flakes provide a good indirect proxy because unless there is a significant change in the number of people participating in cave rites, torch bearing was not likely to have been affected by changes in the material manifestations of the rite itself.

Charcoal flecks were also integral to defining activity areas from excavated contexts. Small artifacts such as these are demonstrated to be important because they are more likely to remain in situ. Thus, they provide stronger reflections of past activity patterns than large objects whose distributions are considerably more likely to have been altered by cleaning, reuse of the area, and scruffage (Balme and Beck 2002; Binford 1968; Rosen 1993; Schiffer 1987; Theunissen et al. 1998).

\section{Chechem Ha Cave}

Chechem Ha is located in the Upper Belize Valley on the western side of the Macal River on the edge of the Vaca Plateau (Figure 3). No settlement centers are associated with the site. Based on the presence of a small uncarved stelae and elite polychrome pottery dating to both the Early and Late Classic periods, it is likely that it served as a local elite pilgrimage center (Awe et al. 2005; Moyes 2006a:35-45,533-535). The closest known surface sites are the midsized Classic period centers of Las Ruinas $6 \mathrm{~km}$ to the northwest and Minanhá located $6.5 \mathrm{~km}$ to the southwest. The Postclassic/colonial period site of Tipu is located 5.8 $\mathrm{km}$ to the north. The large site of Xunantunich is found $9.7 \mathrm{~km}$ northwest, and the agricultural community of Chan Nòohol is $9 \mathrm{~km}$ northwest of the cave.

Chechem Ha is a well-known tourist destination discovered in 1989 and opened to the public in 1995. The owners responsible for the cave's curation have shown a great deal of concern in maintaining the site in the most pristine state possible. This adds to our confidence that the material is in relatively good spatial context, particularly when compared with sites that are continually looted. There are no looters' holes in Chechem Ha, and subsurface deposits are in good condition. In addition, deposits are not as prone to bioturbation because of the lack of plant growth or extensive animal burrowing in the dark zones.

Based on radiocarbon dates, the site was used from the Early Middle Preclassic (1200-800 B.C.), possibly as early as 1300 B.C., to the end of the Late 


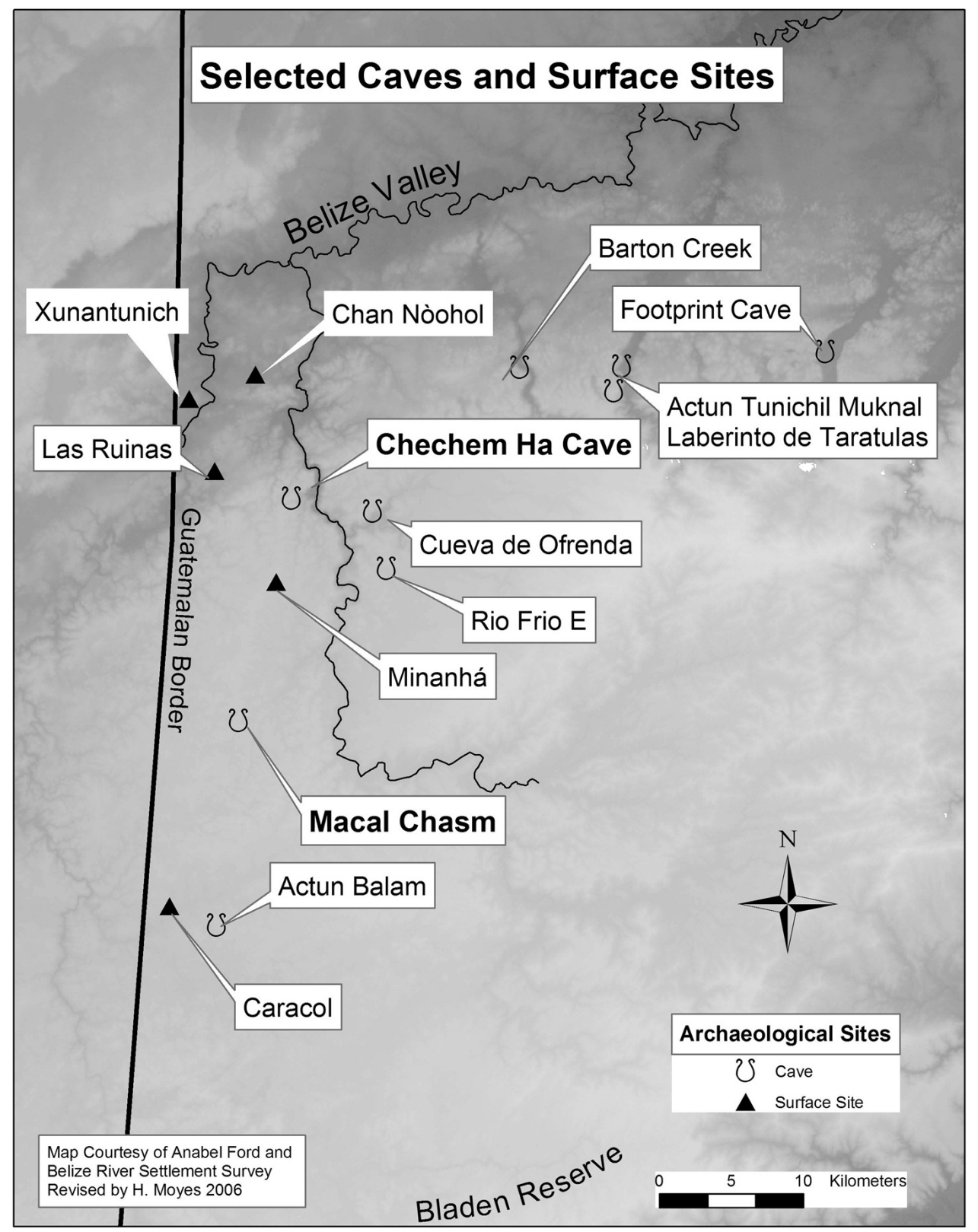

Figure 3. Map of Belize showing sites discussed in text.

Classic period about 950 A.D. (Moyes 2002, 2004, 2006a, 2006b). These are the earliest radiocarbon dates for Maya ritual cave use in the lowlands and are contemporaneous with the first settlers of the Belize Valley (Awe 1992; Garber et al. 2004). Based on accelerator mass spectrometry (AMS) dating of charcoal, the latest date of usage is A.D. 960. There- fore cave use spanned the entire 2,000-year development and collapse of the Classic period sociopolitical system, providing a broad temporal perspective on ritual practice within a single site. Typical of Belizean cave sites, Chechem Ha was not used in the Postclassic period. Postclassic cave use in Belize was ephemeral, consisting solely of a few 


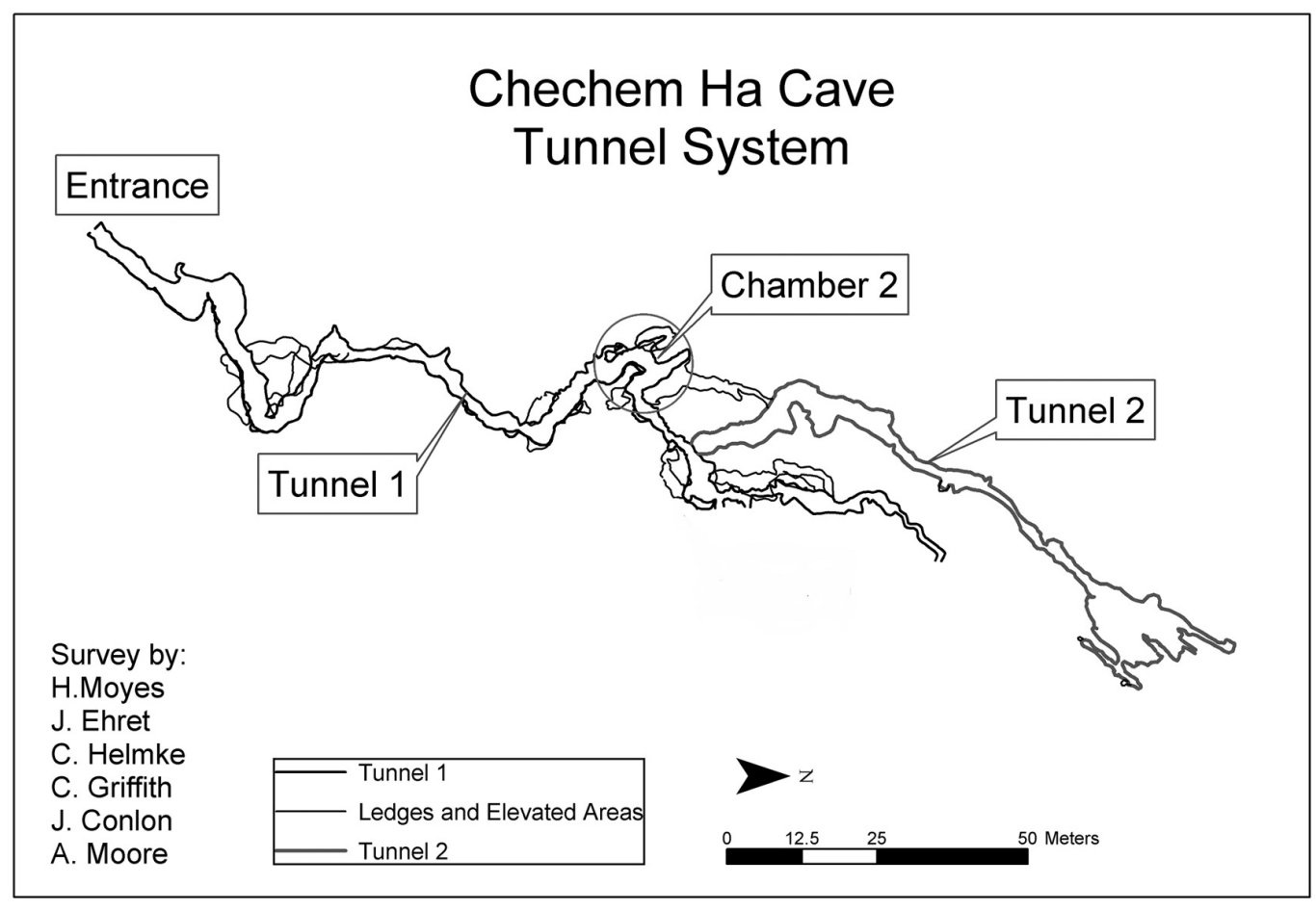

Figure 4. Map of Chechem Ha tunnel system.

sherds left at cave entrances and almost no use of dark zones (Moyes 2006a:579-581).

When William Plytez, son of the landowner, Antonio Morales, discovered the cave in 1989, the entrance was almost completely blocked with medium to large-sized boulders. This intentional blockage suggests that the Maya closed the cave when they abandoned the area sometime prior to A.D. 960. This date correlates roughly with date ranges for the Classic Maya collapse and agrees well with dates from termination events occurring at approximately A.D. 850 from the two nearest surface sites, Las Ruinas de Arenal (Taschek and Ball 1999) and Minanhá (Iannone 2001, 2005).

\section{The Cave System}

The cave sits on a hill $370 \mathrm{~m}$ above sea level and is considered a "dry" cave because it contains no interior water source. It is a complex system, 198 $\mathrm{m}$ in length, that contains over $300 \mathrm{~m}$ of tunnels, consisting of two primary conduits, Tunnel 1 and Tunnel 2 (Figure 4). There are three chambers, four elevated side passages, and 11 shelves located from $3 \mathrm{~m}$ to $7 \mathrm{~m}$ above the Tunnel 1 floor. Arti- facts are found throughout the entire system in niches and alcoves along the floors, in the three chambers, in the elevated passages, and on all 11 shelves.

The tunnel floors are covered with highly plastic, compacted clays mixed and aged bat guano (Moyes 2006a). Chamber 2 contained the deepest subsurface deposits with the clearest stratigraphy. This chamber is centrally located $134 \mathrm{~m}$ from the cave entrance deep within the dark zone. It is situated at a fork in the tunnel so that it is necessary to traverse this area to access the deeper cave passages. The chamber is roughly rectangular in shape, measures $3 \mathrm{~m} \times 8 \mathrm{~m}$, and is oriented on a NE/SW axis (Figure 5). Two ledges containing ceramic artifacts are located above the chamber, Ledge 9 and Ledge 10. Ledge 10 was heavily utilized during the Early Classic period. Two AMS dates suggest a date range of A.D. 240-540 for the ledge. Of note is that almost one-third of the entire ceramic assemblage within the site was located on this ledge. Based on the ceramic chronology, Ledge 9 was used solely in the Late Classic period (700-900 A.D.). Ceramics dating to both the Early and Late Classic periods were found on the chamber floor. 


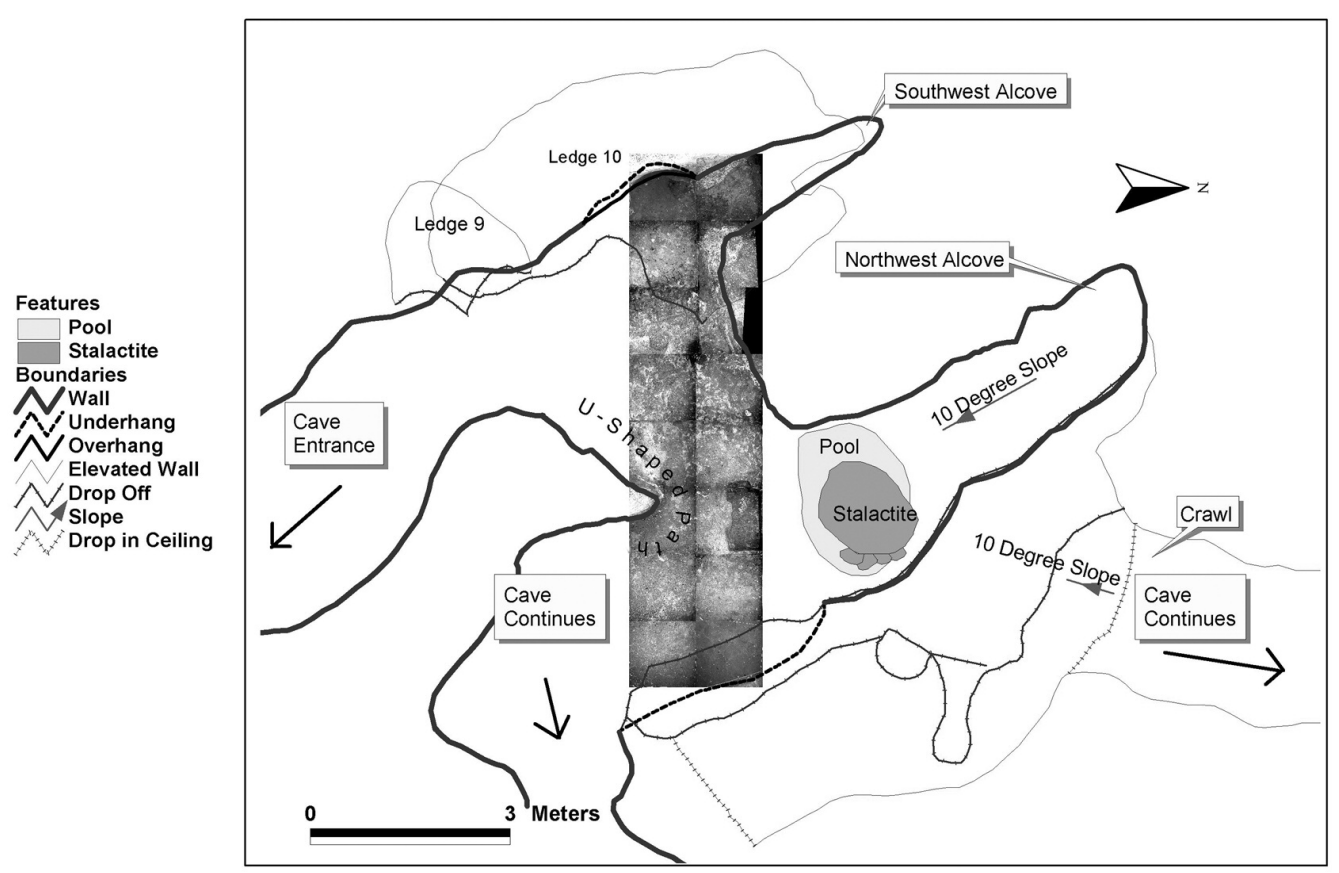

Figure 5. Map of Chamber 2 illustrates morphological features. Photomap bisects chamber.

\section{Methods}

Work at Chechem Ha Cave occurred during four summer field seasons between 1998 and 2003 (Moyes 2006a). To describe changes in ritual behavior in the cave required the collection and analysis of both temporal and spatial data. The entire site was mapped in detail, artifacts were recorded and point plotted, a rigorous dating program was implemented, and test pits systematically placed throughout the system. In the final field season a broad horizontal excavation was conducted in Chamber 2. A geographic information system (GIS) created for the site was instrumental in the data management and analyses.

Chronology in caves is typically difficult to establish because artifacts and features are often surface deposits that are commingled. Their palimpsest nature interferes with the efficacy of absolute dating programs because organics from different temporal periods can sit on the same exposed surface. It is unusual to find deep subfloor deposits in caves and Chechem Ha provided a rare opportunity to evaluate stratigraphic deposits in a cave context. In this case it was possible to use both relative dating of ceramics and absolute dating of organics to establish the cave's chronology.
A total of 44 AMS dates were processed for the site at the University of Arizona Accelerator Mass Spectrometry Laboratory and Beta Analytic, Inc. in Miami, Florida. Dates were calibrated using Oxcal 3.9 and reported at the 2-sigma probability. Areas with no subsurface deposits were dated using ceramic chronologies based on James Gifford's (1976) type-variety-mode system. These data were supplemented with AMS dates derived from charcoal found on surfaces.

Ceramics are one of the most well-represented artifact classes in cave assemblages. At Chechem Ha there were in total 1,901 ceramic entities consisting of sherds and complete or partially complete vessels. An in situ reconstruction determined that these represented a minimum of 563 vessels, of which 113 showed evidence of ritual breakage. Of these, 470 could be typed for chronology (see Moyes 2006a for details).

Changes in the use of space were evaluated both globally and locally. On the global scale, patterns were noted by evaluating the continuities and changes in placement of ceramics within the site using the chronological data. The GIS was instrumental in the analysis because the entire site could be displayed on a single screen and ceramic entities from discrete temporal periods could be 
brought onto the image for visual assessment.

The broad horizontal excavation in Chamber 2 provided data to address both the cave's useintensity and local changes in its use over time. The area was crucial in understanding overall cave use because of its central location within the tunnel system. Because the chamber was located far into the dark zone, it would not have been possible for the ancient Maya users to access the area without artificial light - in this case torches. Therefore the presence of charcoal could be used to calculate use intensity as well as to evaluate activity areas on the excavated levels and assess local changes through time (Moyes 2006a, 2007). The 2-x-8-m excavation extended the entire length of the chamber from the south to the north walls (see Figure 5), and consisted of 17 natural and cultural layers excavated to bedrock. These levels were each AMS-dated and spanned the cave's entire chronological sequence.

To point plot and quantify the numerous charcoal flecks on each excavated surface we used an in-field GIS technology called photomapping developed by Mark Aldenderfer and Nathan Craig (2002; Craig 2000; Craig et al. 2006). The technique employs digital photographs to record each level of the excavation unit. After exposing a level, handheld near-nadir overhead digital photographs were taken of each of the 16 1-x-1-m units using a Nikon CoolPix 950 6-megapixel camera. A 1-m grid that mirrored the excavation units was constructed in the GIS. Unit corners visible in both the excavation unit photographs and the GIS computer model served as ground control points of known location. These points were used to apply affine transformations to each of the unit photographs in order to correct for scale, skew, and rotation. Image geo-referencing placed the individual unit photographs into their proper spatial context. After each individual unit photograph was georeferenced we constructed a photomosaic that is a single composite image covering a level's entire exposed extent. Each excavation level was recorded as a separate layer in the GIS. Features and artifacts were easily digitized onto the geo-referenced mosaic as either points or polygons using a Fujitsu Stylistic tablet computer. All artifacts were represented as a distribution of points, and recording was done in situ to ensure accuracy.

Charcoal distributions documented in the photomaps were analyzed to assess the changes in the use of space in the chamber. Density difference maps were generated to illustrate areas of the highest densities by subtracting the observed points from a uniform distribution of points. The aim of the analysis was to define areas having greater than expected distributions. This product represented zones that have relatively more or fewer objects than expected given a completely uniform distribution. For visualization purposes, we applied a standard deviation stretch with a two-color palette. (For further details regarding this method, see Craig et al. 2006; Moyes 2006a, 2008; Moyes et al. 2006.)

\section{Results}

The ceramic chronology from both surface and subsurface contexts determined that 4 percent were from the Cunil/Jenney Creek complex of the Early/Middle Preclassic period (1200-300 B.C.), 5 percent were from the Barton Creek complex of the Late Preclassic period (600-100 B.C.), only two sherds dated to the later part of the Late Preclassic Mt. Hope Complex (100 B.C.-A.D. 250), 39 percent dated to the combined Terminal Preclassic/Early Classic or Floral Park/Hermitage period (250-600 A.D.), 2 percent dated to the early Late Classic Tiger Run complex (600-700 A.D.), and 51 percent dated to the Late Classic Spanish Lookout complex (700-900 A.D.). Based on these figures, one might at first glance expect that the cave underwent its most intensive usage in the Late Classic period, but this is not a safe assumption. Because ceramics are portable objects brought into the cave as offerings or as objects used in rituals, the assemblages are likely to be affected by changes in ritual practices.

Proxy measures based on charcoal flecks excavated from Chamber 2 suggest that there was very little use-intensity in the Late Classic period. Levels $1-13$ in the excavation dated to the Maya era. Level 1 was the modern ground surface. This level was AMS dated to the Early Classic, but Late Classic ceramics sat on the chamber floor, clearly demonstrating its use at that time. Levels 2-6 dated to the Early Classic period; Level 7, to the Late Preclassic; and Levels 8-13, to the Early/Middle Preclassic. The number of charcoal flecks per level ranged from 265 to 8,244 (Table 1). As the excavations progressed the cave walls curved inward and spatial areas narrowed toward the bottom. 
Table 1. Excavation Results for Chamber 2 Showing Maya Levels 1-13 with AMS dates.

\begin{tabular}{|c|c|c|c|c|c|c|}
\hline Level & $\begin{array}{c}\text { AZ Lab\# } \\
\text { (Beta Analytic) }\end{array}$ & $\begin{array}{c}\text { AMS Date and } \\
\text { Calibrated } 2 \sigma\end{array}$ & Period & $\begin{array}{l}\text { Excavated } \\
\text { Area }\left(\mathrm{m}^{2}\right)\end{array}$ & $\begin{array}{c}\text { Surface } \\
\text { Charcoal }\end{array}$ & $\begin{array}{l}\text { Use-Intensity } \\
\text { Index }\end{array}$ \\
\hline 1 & Beta170074 & $\begin{array}{c}1660 \pm 40 \\
\text { A.D. } 250-540\end{array}$ & Early Classic & 12.77 & 265 & 20 \\
\hline 2 & AA57272 & $\begin{array}{c}1673 \pm 34 \\
\text { A.D. } 250-440\end{array}$ & Early Classic & 12.61 & 770 & 61 \\
\hline 3 & AA57271 & $\begin{array}{c}1587 \pm 34 \\
\text { A.D. } 400-560\end{array}$ & Early Classic & 12.47 & 2,155 & 175 \\
\hline 4 & AA57273 & $\begin{array}{c}1668 \pm 34 \\
\text { A.D. } 250-440\end{array}$ & Early Classic & 12.76 & 1,779 & 139 \\
\hline 5 & AA57274 & $\begin{array}{c}1685 \pm 39 \\
\text { A.D. } 240-440\end{array}$ & Early Classic & 12.3 & 3,341 & 272 \\
\hline 6 & AA57275 & $\begin{array}{c}1744 \pm 40 \\
\text { A.D. } 130-420\end{array}$ & $\begin{array}{c}\text { Terminal Preclassic/ } \\
\text { Early Classic }\end{array}$ & 12.58 & 8,244 & 664 \\
\hline 7 & AA57276 & $\begin{array}{c}2120 \pm 34 \\
350-40 \text { B.C. }\end{array}$ & Late Preclassic & 12.58 & 815 & 66 \\
\hline 8 & AA57277 & $\begin{array}{c}2826 \pm 34 \\
1130-890 \text { B.C. }\end{array}$ & $\begin{array}{l}\text { Early Middle } \\
\text { Preclassic }\end{array}$ & 10.06 & 1,290 & 130 \\
\hline 9 & AA57278 & $\begin{array}{c}2755 \pm 35 \\
1000-820 \text { B.C. }\end{array}$ & $\begin{array}{l}\text { Early Middle } \\
\text { Preclassic }\end{array}$ & 10.1 & 2,884 & 291 \\
\hline 10 & AA57279 & $\begin{array}{c}2760 \pm 34 \\
1000-820 \text { B.C. }\end{array}$ & $\begin{array}{c}\text { Early } \\
\text { Preclassic }\end{array}$ & 9.97 & 3,537 & 354 \\
\hline 11 & AA57280 & $\begin{array}{c}2865 \pm 33 \\
1190-920 \text { B.C. }\end{array}$ & $\begin{array}{c}\text { Early } \\
\text { Preclassic }\end{array}$ & 9.47 & 1,390 & 147 \\
\hline 12 & AA57281 & $\begin{array}{c}2931 \pm 62 \\
1320-930 \text { B.C. }\end{array}$ & $\begin{array}{c}\text { Early } \\
\text { Preclassic }\end{array}$ & 9.27 & 1,591 & 172 \\
\hline 13 & AA57282 & $\begin{array}{c}2847 \pm 34 \\
1130-910 \text { B.C. }\end{array}$ & $\begin{array}{c}\text { Early } \\
\text { Preclassic }\end{array}$ & 10.25 & 917 & 89 \\
\hline
\end{tabular}

Therefore a correction to the raw data was made because the excavated surface areas were not of identical size on each level. A use-intensity index was derived by dividing the number of flecks for each level by the area of the excavated level.

Figure 6 illustrates the variation between levels. Beginning in the Early/Middle Preclassic period there is heavy usage that falls off after 820 B.C. There is a little usage in Level 7 that dates to $350-40$ B.C. but is bracketed by much earlier and later dates, suggesting that the chamber received lowintensity usage for a long period of time. Level 6 is the period of heaviest use and dates from the Terminal Preclassic to the beginning of the Early Classic period, A.D. 210-420. Over the Early Classic its usage wanes, and by the Late Classic period there is very little use of the chamber.

When we view the two data sets side by side we find both agreement and discrepancies between the ceramic and charcoal proxies (Figure 7). In the Early/Middle Preclassic period charcoal counts are high but ceramic counts are at their lowest, suggesting intensive site usage at this early period but little importation of ceramics. Both data sets show low amounts of both charcoal and ceramics in the Late Preclassic period, which suggests sparse usage of the site. During the Early Classic period both the ceramic counts and charcoal indexes increase considerably, suggesting an intensification of use. In the Late Classic period the ceramic data suggest that there is greater intensity of use than indicated by the amount of charcoal found on the surface. The increased number of ceramic vessels coupled with the sparse charcoal deposits suggests that the ceramic deposition became the major focus of cave ritual at this time.

The spatial use of Chamber 2 also differs between the Early and Late Classic periods. Figure 8 shows density difference maps for Levels 1 and 2. Level 1 is the modern use surface, and although two AMS dates from the level demonstrate that the deposit dates to the Early Classic period, Late Classic sherds located on the surface indicate that it was used in the Late Classic as well. Level 2 dates to the Early Classic period (A.D. 240-440). 


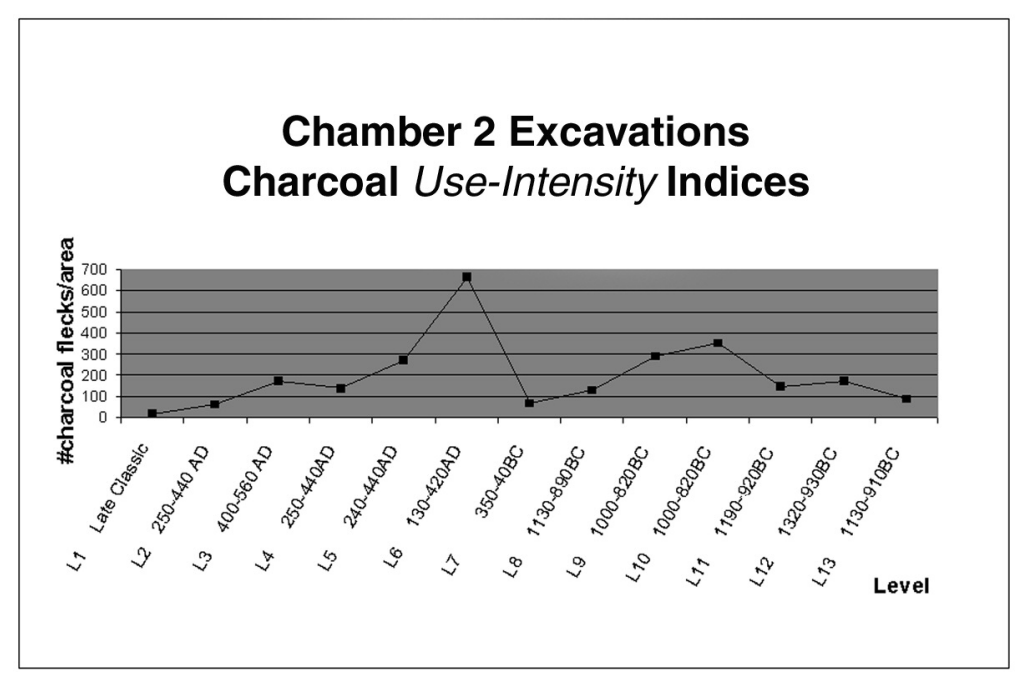

Figure 6. Graph of use-intensity index shows numbers of charcoal flecks by excavated level divided by surface area of excavated space.

Charcoal densities on Level 1 occurred primarily below Ledge 9, that was used in the Late Classic period. Late Classic sherds also accompanied the charcoal scatter beneath an overhang below the ledge, which accounts for the large density cloud in that location. The remainder of the chamber shows little use. The pattern suggests that people were entering the area and using Ledge 9 but not lingering in the chamber. People were certain to have passed through the chamber to enter the deeper areas of the cave but left little trace. The map of Level 2, dating to the Early Classic period, illustrates a more diffuse pattern of use with multiple density clouds occurring throughout the chamber. This pattern suggests a different pattern of ritual activity. People were likely to be standing or moving about the chamber conducting activities of longer duration either in larger groups or with more frequency.

Change in the use of space between the Early

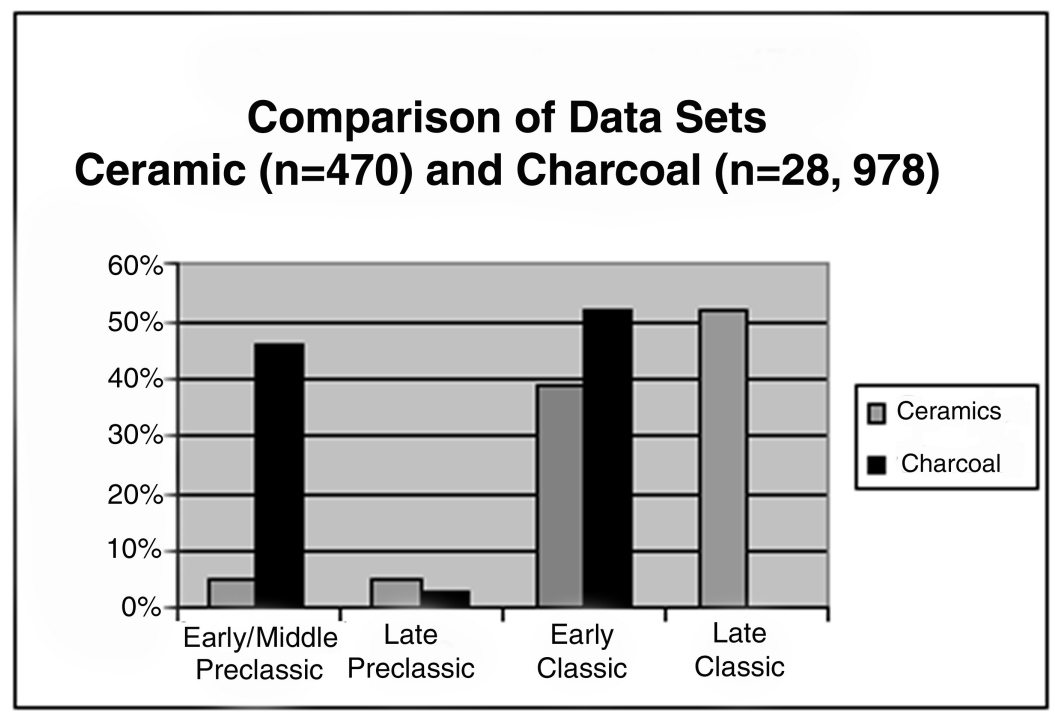

Figure 7. Chart shows the percentages of ceramic and charcoal data sets for each major temporal period. There is less than 1 percent of the total number of charcoal flecks on the surface of Chamber 2. 


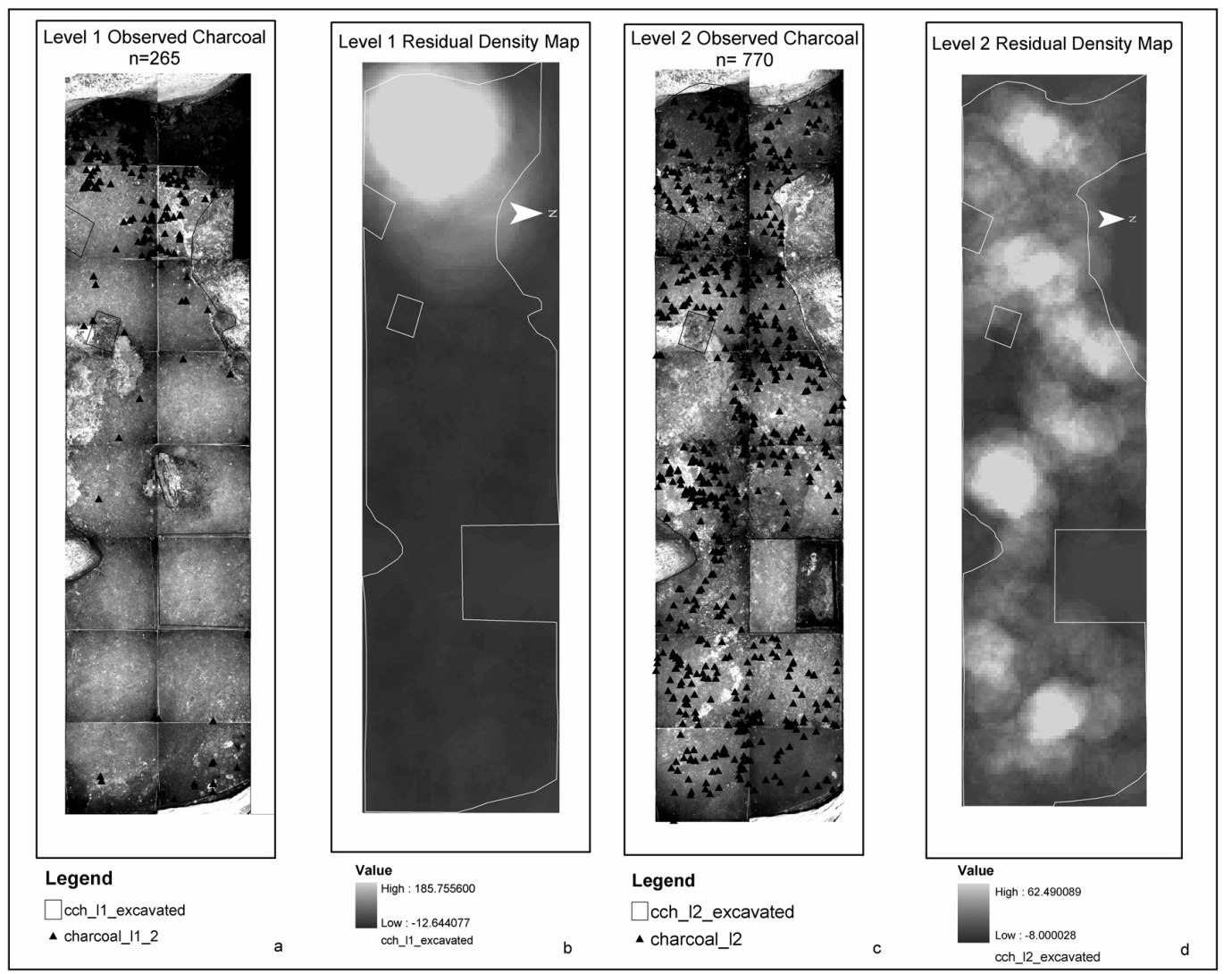

Figure 8. Density difference maps illustrating the difference in activity areas between the Early and Late Classic period a) observed charcoal on Late Classic Level 1, b) residual density on Late Classic Level 2, c) observed charcoal on Early Classic Level 2, b) residual density on Early Classic Level 2. Density cloud is only found adjacent to the west wall in the Late Classic whereas the charcoal density is diffused throughout the chamber in the Early Classic period.

and Late Classic periods also occurred on a global scale. The maps in Figure 9 illustrate the spatial variation of diagnostic ceramics for these two periods. The Early Classic distributions occurred in three major areas: the passage leading to Chamber 2, Ledge 10 located in Chamber 2, and in the deepest passages of Tunnel 1. In the Late Classic period Ledge 10 fell out of use, but the other 10 ledges were used for the first time. In addition to the ledges, artifacts were also placed in the elevated passages, crawl spaces, and other areas that were spatially restricted and difficult to access. While some of these spaces were used sparsely in earlier periods, it was not until the Late Classic that they became the activity areas of choice.

Finally, the condition of the ceramic assemblage changed between the Early and Late Classic periods. In the Early Classic complete or partially intact vessels were rare, represented by a single intact jar and a partially intact polychrome dish. In the Late Classic period there were 51 complete vessels and numerous others that were partially intact. Figure 10 illustrates the typical condition of the two assemblages. Some Late Classic jars were found in either upright or inverted positions with large, widemouthed, Mt. Maloney-style bowls inverted over them or placed nearby. In one case two bowls were placed over the base of an inverted jar (Figure 11). The jar/bowl configuration is reminiscent of similar finds at the Templo Mayor representing the celestial pouring of water from the sky by Tlaloc (discussed above). Although the majority of the intact Late Classic vessels were jars or large bowls, partially intact monochrome and polychrome dishes and vases from the period were found in elevated passages and crawls and in Tunnel 2.

Two intact, lidded vessels contained the remains of underdeveloped ears of 10-rowed Zea mays 

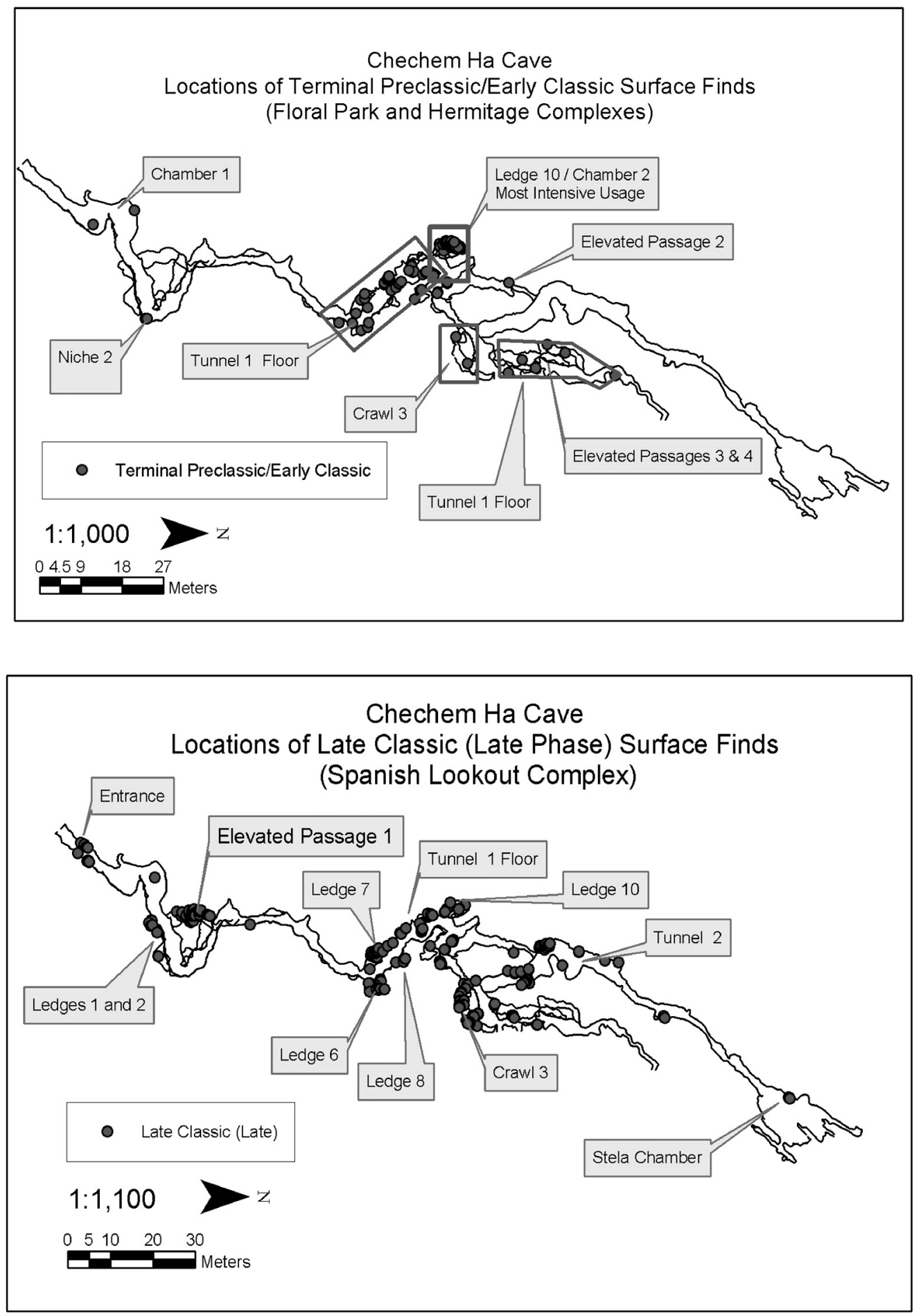

Figure 9. Maps of cave illustrating differences in the distributions of ceramics between the Early (top) and Late (bottom) Classic periods. In the Late Classic ceramics are more widely distributed throughout the site. Ledges and high level passages become the preferred activity areas at this time. 


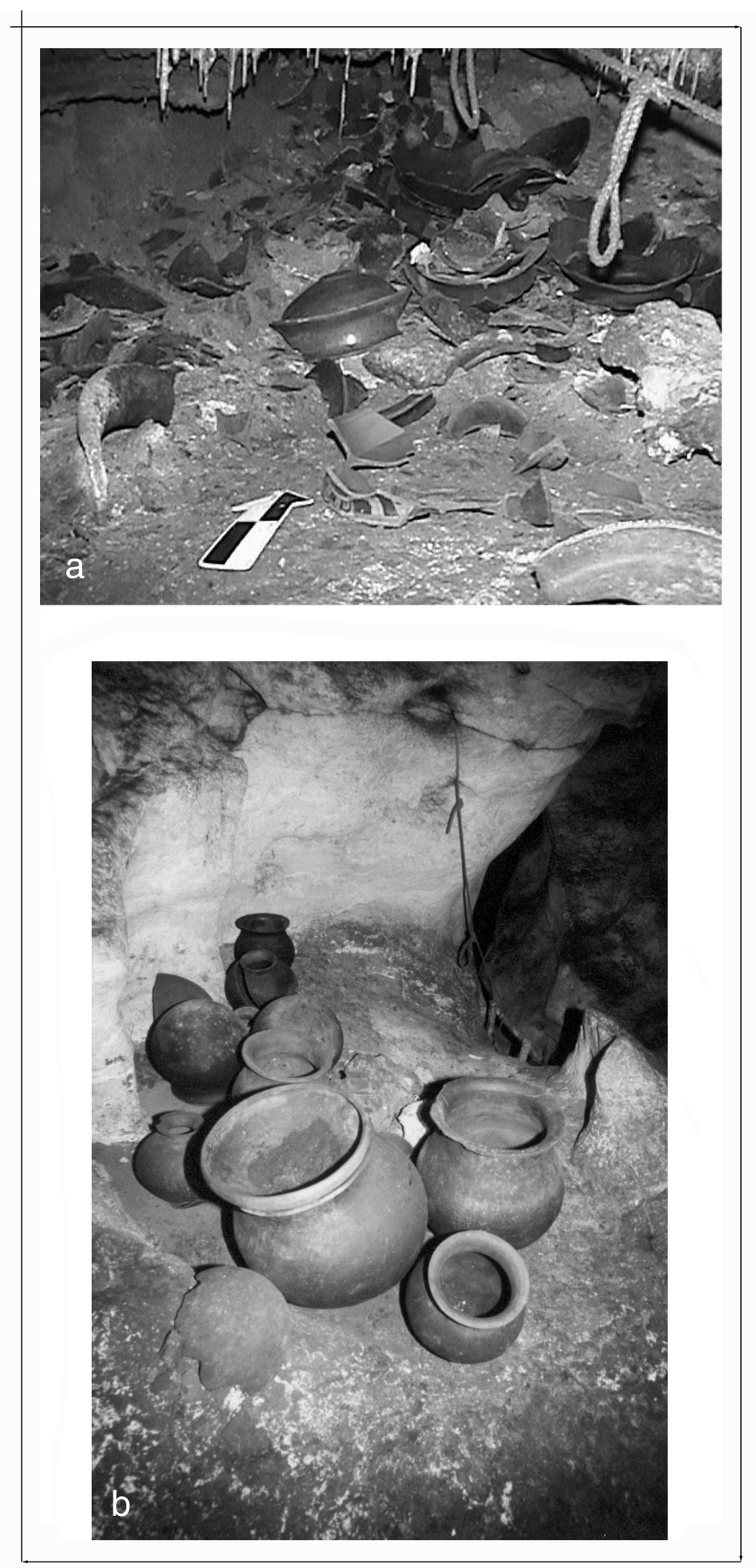

Figure 10. Photo illustrating differences between typical Early and Late Classic cave ceramic assemblages. a) Early Classic assemblage is highly fragmented whereas b) Late Classic assemblage contains more whole or partial vessels (Photos by H. Moyes, 2003). 


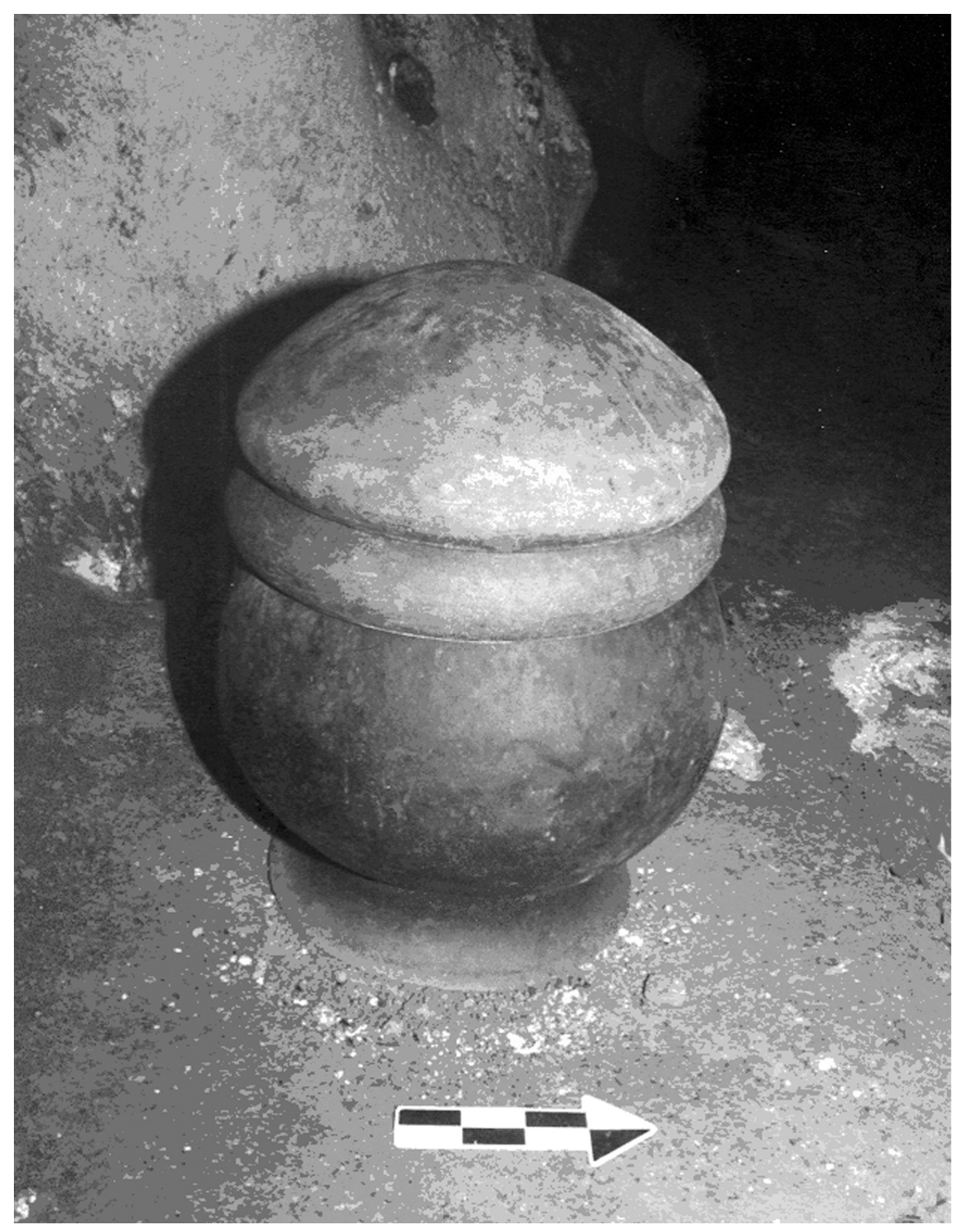

Figure 11. Jars placed with bowls covering their openings in Tunnel 2 (Photo by H. Moyes, 2003).

(Morehart 2002:168-172). It is argued elsewhere that this represents "first fruit" or harvest rites (Morehart 2005:175; Moyes 2006a:526, 556-557). Direct dating of the cobs indicates that the offerings were made in the Late Classic period between A.D. 680 and 900 (Table 2). None of the other jars in the assemblage contained visible residues, suggesting that the vessels themselves were the intended offerings. One might argue that ethnobotanic remains may have entirely disintegrated, but this is unlikely, as evidenced by the excellent preservation of the maize in two different areas of the cave. Additionally, in partially intact jars, bases were missing from both lidded and unlidded ves- sels, precluding their use as containers for either ethnobotanical or liquid offerings.

Five dates obtained from material on ledges and Elevated Passage 3 confirm that this change in practice occurred sometime after A.D. 680 (see Table 2). To summarize: during the Late Classic period over 51 percent of the ceramic assemblage was imported into the site over a relatively short time span between A.D. 680 and 960, which suggests that during this time the deposition of ceramic vessels became the major focus of cave rites. Not only this, but there is a change in the condition of the vessels. More complete or semi-intact vessels were deposited in the Late Classic than in all other tem- 
Table 2. Late Classic Accelerator Mass Spectrometry Dates Calibrated Using OxCal 3.9.

\begin{tabular}{|c|c|c|c|c|c|}
\hline $\begin{array}{l}\text { Arizona } \\
\text { Lab \# }\end{array}$ & Period & Area & $\begin{array}{c}\text { AMS Date } \\
\text { and Calibrated } 2 \sigma\end{array}$ & $\begin{array}{c}\text { Alternative } \\
\text { Probabilities }\end{array}$ & Material \\
\hline AA57293 & Late Classic & Ledge 6 & $\begin{array}{c}1187 \pm 33 \\
\text { A.D. } 720-960\end{array}$ & $\begin{array}{c}(83.3 \%) \\
\text { A.D. } 770-900\end{array}$ & Charcoal \\
\hline AA57288 & Late Classic & Ledge 4 & $\begin{array}{c}1210 \pm 31 \\
\text { A.D. } 690-900\end{array}$ & $\begin{array}{c}(85.4 \%) \\
\text { A.D. } 760-900\end{array}$ & Charcoal \\
\hline AA59754 & Late Classic & Ledge 6 & $\begin{array}{c}1224 \pm 38 \\
\text { A.D. } 680-900\end{array}$ & $\begin{array}{c}(68.2 \%) \\
\text { A.D. } 720-890\end{array}$ & Corn \\
\hline AA59753 & Late Classic & $\begin{array}{c}\text { Elevated } \\
\text { Passage } 3\end{array}$ & $\begin{array}{c}1239 \pm 36 \\
\text { A.D. } 680-890\end{array}$ & $\begin{array}{c}(68.2 \%) \\
\text { A.D. } 690-870\end{array}$ & Corn \\
\hline AA57291 & Late Classic & Ledge 7 & $\begin{array}{c}1244 \pm 31 \\
\text { A.D. } 680-890\end{array}$ & $\begin{array}{c}(68.2 \%) \\
\text { A. D. } 690-860\end{array}$ & Corn \\
\hline
\end{tabular}

poral periods combined. Activity areas shifted from the tunnel floor to high ledges and other areas that were remote or difficult to access. Although a large number of whole or partially intact ceramic vessels were deposited at the site in the Late Classic period, charcoal use-intensity data suggest that this was accomplished by small groups. Additionally, the number of participants in these rites was limited by the choice of activity areas, such as those located on small high ledges or in restricted spaces that could accommodate only a few people. The sparse deposits of charcoal on surfaces in Late Classic contexts, as evidenced in Chamber 2, precludes participants from having spent long periods of time in the cave as longer rites would have produced greater amounts of charcoal rain from torches. These findings suggest that in the Late Classic period groups entered the cave and conducted rituals of short duration in restricted areas. This, coupled with the numerous ceramic vessels, indicates that individuals deposited the vessels as the primary focus of the ritual, then, exited the cave without further activity.

\section{A Regional Phenomenon}

Having established a Late Classic pattern of usage at Chechem Ha, it was then possible to look for this pattern at other sites. We found that the placement of intact and partially intact Late Classic (Spanish Lookout-style) jars in remote or difficult-to-access areas is a widespread phenomenon in Belizean cave sites. In our collective research we have noted that every cave in central and southern Belize has evidence for ancient Maya use during the Late Classic period and many caves only came into use at that time. Northern cave sites are conspicuously missing from our data set primarily because there are few known sites in Belize north of the Belize Valley and none that has been systematically investigated or well dated.

Some of the most systematically collected data are from unlooted sites investigated by the WBRCP. Actun Tunichil Muknal, located on the Roaring Creek, is the best example. It was fully recorded and dated using both the ceramic chronology and radiocarbon (Moyes 2001, 2005b; Moyes and Awe 1998, 2000). The site, discovered and mapped by Thomas Miller in 1989 (Miller 1989, 1990), is a 4$\mathrm{km}$ cave system with evidence of ritual use in the twilight areas near the entrance and in three venues deeper within the tunnel system. The two areas located deepest within the system, the Stela Chamber and the Main Chamber, date to the Late Classic era, while other areas show evidence of Early Classic use (Helmke 1999). The Main Chamber, located $500 \mathrm{~m}$ from the entrance, was the cave's most remote and esoteric ritual venue. Based on the ceramic chronology and two AMS dates, the Main Chamber was used between A.D. 710 and 960, coinciding with the Late Classic use pattern at Chechem Ha. Of the 718 vessels located within the chamber, 54 percent are medium to large-sized jars. Many were complete or partially intact, and although the chamber itself was quite remote, caches of these vessels were found in restricted niches and alcoves located above the chamber floor; and a number of these vessels were arranged on an altar-like platform (Figure 12). The Late Classic use-pattern was also noted in the Roaring Creek area at the site of Yaxteel Ahau. Ledge 2, located $300 \mathrm{~m}$ into the dark zone, $15 \mathrm{~m}$ above the watery tunnel passage, contained ceramics dating only to the Late Classic period (Owen and Gibbs 1999). 


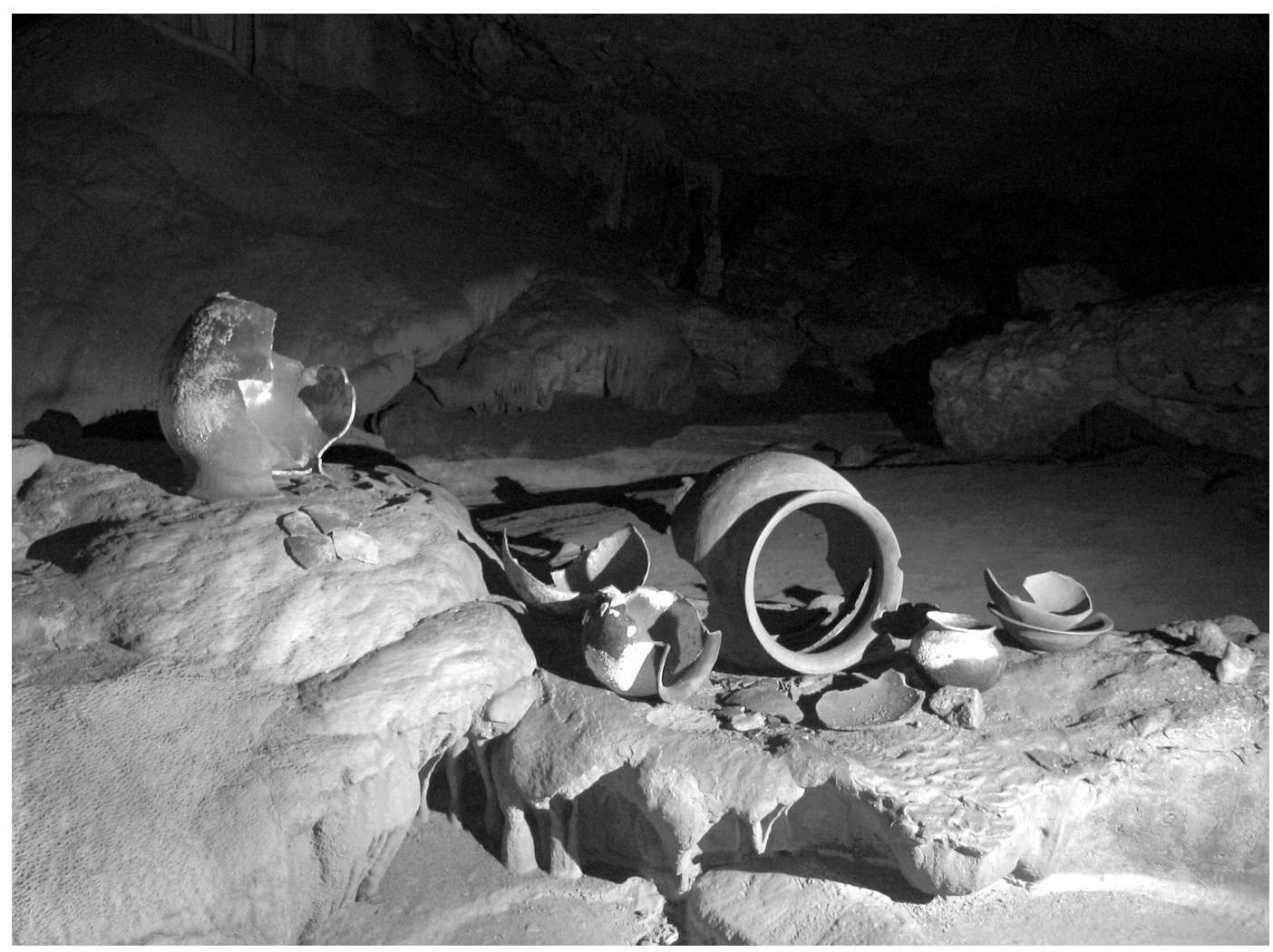

Figure 12. Late Classic vessels placed on a platform or altar at Actun Tunichil Muknal (Photo by John Lyles 2003).

Also, as evidenced by the ceramic chronology, the nearby Laberinto de las Tarantulas, a small cave site consisting solely of narrow tunnels and crawl spaces, was only used in the Late Classic period (Helmke et al. 1999).

Barton Creek Cave located in the Barton Creek Valley near Progreso (Seven Mile) village is a wellknown tourist venue that has been visited for many years. While a great deal of looting has occurred, some ledges that were difficult to access because they were located high above the river that runs through the site, contained intact archaeological material (Mirro and Mirro 2001; Morehart et al. 2004). Here again, the Late Classic pattern may be observed. For instance, on Ledge 2 in Area C, a Late Classic jar sat on a ledge above the chamber. The jar was missing its base, but it had been placed beneath a drip, and a calcite crust covered the vessel. Area $\mathrm{H}$, a small and difficult-to-access niche located above the ledge, contained a ceramic cache including a complete Late Classic dish and a partially intact jar. A large complete jar with a kill hole sat below the cache. On Ledge 3 in Area A, in a small chamber partitioned by calcite formations, a complete Late Classic Spanish Lookout-style jar sat adjacent to an intermittent pool. A similar configuration was present in Area B, another small enclosure partitioned by calcite draperies. As with all of the other sites, there were very few or no intact vessels from earlier temporal periods found in the cave.

Moyes's recent survey of 53 previously recorded and unrecorded caves from the Mountain Pine Ridge to the Guatemala border shows evidence of the Late Classic use-pattern throughout the region, even in heavily looted sites (Moyes et al. 2006). The most notable example of an unrecorded site that manifests the Late Classic pattern is Cueva de Ofrenda (Offering Cave or Ka'am), a large complex cave system located at the northern edge of the Mountain Pine Ridge near the town of San Antonio. Although the cave has sustained heavy looting, caches of medium to large Late Classic Spanish Lookout-style vessels were found on natural shelves along the southernmost wall in the deepest area of the cave. It is unlikely that these 
vessels were moved to the area by looters or others due to the fragility of jars of this size found in humid cave environments.

Without the benefit of detailed spatial analyses, radiocarbon dates, and ceramic chronologies, evidence of the Late Classic pattern is more difficult to discern in previously recorded sites, though a number of reports indicate that the pattern exists in other areas of Belize. Many of these older studies did not benefit from refined ceramic chronologies and used ceramic cross-dating with the Peten; but some of these reports are quite detailed, so that basic conclusions may be inferred from them. One pattern that is discernable is the presence of a large number of jar forms in caves in the Late Classic period. This pattern is noted at Petroglyph Cave (Reents-Budet and MacLeod 1997:50-58), Eduardo Quiroz Cave (Pendergast 1971), Actun Polbiche (Pendergast 1974), and Actun Balam (Pendergast 1969). Also of note is the placement of whole or partial vessels in locations that are remote or difficult to access.

In the Sibun area, Patricia McAnany and her colleagues (2003) report large Late to Terminal Classic vessels in inaccessible areas at Pottery Cave. David Pendergast (1974) also found numerous intact and partially intact Late Classic jars and dishes at Actun Polbilche in the Sibun Hills. His ceramic typology is supported by a single radiocarbon date reported at 1-sigma that places the latest cave use about A.D. 735. The ceramic caches were in the most remote areas of the cave in Alcoves I and II. Pendergast considered Polbiche to be the "the driest cave known" and even suggests that it was seen by the ancient Maya as "a sort of representation of drought, and the best possible site for placement of offerings designed to bring arid disasters to an end" (1974:82).

Pendergast (1969) also investigated Actun Balam, located in the Chiquibul Reserve near the site of Caracol. The cave contained a midden of 22,000 sherds dating to the Late to Terminal Classic period that had clearly been deposited by dropping vessels down a shaft from the surface. According to Pendergast, the latest datable object was a Pabellon Modeled-Carved vessel that was initially thought to be Early Postclassic but has now been more securely dated to the Late to Terminal Classic period (Awe 1985; Helmke 2005). Based on his reconstruction of the ceramics from the site,
Pendergast suggests that jars full of water were brought to the cave and thrown down the shaft. While it is impossible to determine if the jars actually contained water, this does suggest that intact jars were an important offering at the site during this period.

At nearby Eduardo Quiroz Cave, Pendergast (1971:121, Plate 6, and 120, Plate 4) reported a cache of intact and partially intact Late Classic Spanish Lookout-style vessels located in Chamber 6 , the deepest area of the cave. The vessels were found within a niche running along the easternmost edge of the chamber. A similar vessel cache was found on a ledge above Chamber 2. Also in this region at Rio Frio Cave E, Pendergast (1970), reporting for A. H. Anderson, described unlooted "inaccessible" ledges and alcoves at the site that contained intact or partially intact jars and bowls dating to the Late Classic period. Pendergast noted the abundance of Late Classic material from all the caves in the Mountain Pine Ridge, which led him to suggest that the caves had been used solely during this time period. This agrees with observations by the WBRCP that there was an intensification of overall cave use during the Late to Terminal Classic periods.

In the Caves Branch area Graham and her colleagues (1980) illustrated a number of intact or partially intact Late Classic jars and bowls found on a high ledge at Footprint Cave. Observations based on ceramic chronologies from nearby Petroglyph Cave (Reents-Budet 1980:268-269) suggested that entrances and light zones were utilized at earlier time periods than dark zones. This observation has led a number of scholars to think that utilization progressed deeper into the cave's interior at later time periods, but evidence from Chechem $\mathrm{Ha}$ demonstrates that this is not entirely correct because esoteric areas such as high ledges or elevated passages can be located near entrances. However, the Petroglyph data do fit the Late Classic deposition pattern. Dorie Reents-Budet and Barbara MacLeod (1997:36) discuss an intact Late to Terminal Classic bowl discovered in the Upper Grotto, the highest ledge of the cave, and note an intact black jar of unknown date found cached in the area.

Farther south in the in the Toledo district's Bladen Reserve, in his survey of 48 caves, Keith Prufer (2002) reported numerous sites containing whole or partially intact Late Classic vessels placed 
in areas that were difficult to access or remote from entrances. Even farther south at the cave of Hokeb Ha at Blue Creek, Joseph Palacio (1977) reported finding 24 Late to Terminal Classic vessels. The cave is accessed via a sheer inaccessible cliff face or by ascending cave passages within the adjoining Blue Creek Cave. The vessels consisted of whole or partial vases, bowls, incensarios, and jars, some of which appeared to have been broken in situ. Nine of these were complete jars.

Both formal studies and informal observations from Belizean sites indicate that Late Classic cave use has unique features that distinguish it from use during other temporal periods. Not only this, but there was a dramatic increase in the number of caves used during this period. Although some might argue that population increases could account for increased use, this would not explain changes in practice. Because of the relationship of caves to rain control and fertility, we suspected that ritual transformations correlate with a change in environmental conditions.

\section{Local Paleoenvironmental Reconstruction}

Cave stalagmites can be a valuable source of highresolution, local climate data and can be very accurately dated by inductively coupled plasma mass spectrometry uranium-series (ICPMS U-series (e.g., Ford and Williams 1989; Hill and Forti 1997; Schwarcz and Rink 2001). Variations in stalagmite petrography, oxygen and carbon isotopes, color, and UV-stimulated luminescence are often climate proxies and can be measured at very high resolution. Variations in color and luminescence can be resolved at the subannual level, depending on the rate of deposition of the stalagmite and the resolution at which the stalagmite surface is digitally imaged.

A recent study of a stalagmite from western Belize has added to the growing body of evidence for major droughts in the Maya Lowlands coincident with the "collapse.” James Webster and his colleagues (Webster 2000; Webster et al. 2007) have produced a proxy record of rainfall by analyzing a 92-cm-long stalagmite from the Macal Chasm located on the Vaca Plateau approximately $15 \mathrm{~km}$ from Chechem Ha Cave. The entrance to Macal Chasm is a vertical shaft $5 \mathrm{~m}$ in diameter and $40 \mathrm{~m}$ deep that opens into the ceiling of a large chamber measuring $62 \mathrm{~m} \times 45 \mathrm{~m}$. The stalagmite was removed from this chamber at a point about $8 \mathrm{~m}$ southwest of the vertical entrance shaft.

ICPMS U-series and ${ }^{210} \mathrm{~Pb}$ ages (for the last century of deposition only) indicate that the upper 48 $\mathrm{cm}$ of the stalagmite was deposited over the last $3,300 \pm 310$ years. Relative rainfall was assessed by evaluating variations in petrography, stable isotopes, grayscale color, and luminescence, which served as proxies for past conditions. Petrographic analysis and X-ray diffraction revealed that the stalagmite is composed largely of dense translucent calcite with lesser zones of white porous calcite. The porous calcite was deposited beneath a thin water film on the stalagmite that would occur during dry climate intervals. By contrast, the dense translucent calcite records deposition beneath a thicker water film during wetter conditions. In addition, there are distinct detritus-rich layers in both the dense and porous calcite. We think that detritusrich layers in the porous calcite formed during drier periods when drip water rates slowed or nearly stopped. The detrital material was probably deposited as an aerosol when drip water failed to wash dust off the surface of the stalagmite.

The $\delta^{18} \mathrm{O}$ of stalagmite carbonate is influenced by the temperature at deposition and by the $\delta^{18} \mathrm{O}$ of the precipitating drip water. In tropical caves, temperature does not vary significantly, and so the isotopic composition of the drip water is the primary control on the stalagmite $\delta^{18} \mathrm{O}$. In Macal Chasm this value is controlled by the $\delta^{18} \mathrm{O}$ of the rainfall and by evaporation due to the location of the stalagmite near the entrance to the cave. Generally, heavier and more prolonged rains have lower $\delta^{18} \mathrm{O}$ and would likely allow less evaporation under more humid conditions. The result should be lower $\delta^{18} \mathrm{O}$ values in carbonate deposited on the stalagmite. In contrast, low-intensity and short-duration rains have higher $\delta^{18} \mathrm{O}$, and under the drier conditions would allow more evaporation, which would further increase $\delta^{18} \mathrm{O}$ values of carbonate deposited on the stalagmite. Wet and dry periods were therefore inferred from variations in the stable isotope composition $\left(\delta^{18} \mathrm{O}\right)$ of the stalagmite carbonate, with high values suggesting dry conditions and low values, much wetter conditions (Webster et al. 2007).

The $\delta^{13} \mathrm{C}$ of stalagmite carbonate is determined by the $\delta^{13} \mathrm{C}$ of the carbon dioxide in the soil above 
the cave, the degree to which open-system dissolution of limestone occurs, and the extent of $\mathrm{CO}_{2}$ outgassing once the water reaches the cave. Currently, the vegetation is largely $\mathrm{C}_{3}$, being typical of wetter climates. During past drier phases it is possible that there was a modest increase in the content of $\mathrm{C}_{4}$ plants in the plant cover, resulting in a slight increase in the $\delta^{13} \mathrm{C}$ of the soil $\mathrm{CO}_{2}$ (Brook 1999).

Probably more important is that during dry periods there would be reduced plant growth and so less soil $\mathrm{CO}_{2}$ in percolating waters. Low levels of soil $\mathrm{CO}_{2}$ would limit carbon exchange in the soil zone, causing $\delta^{13} \mathrm{C}$ to increase also. Thus wetter conditions at Macal Chasm should result in lower $\delta^{13} \mathrm{C}$ because of higher levels of soil $\mathrm{CO}_{2}$. Under closed-system conditions the percentage of dissolved carbon in percolating waters that is derived from the host rock increases as soil $\mathrm{PCO}_{2}$ decreases (Hendy 1971). At Macal Chasm, upland soils are relatively thin, and infiltration rates during intense rains are high. As the stalagmite grew more than $50 \mathrm{~m}$ below the surface, it is likely that some dissolution of carbonate occurred under closed-system conditions. Therefore, in dry years the $\delta^{13} \mathrm{C}$ of drip water and of carbonate precipitated on the stalagmite would increase because of lower soil $\mathrm{PCO}_{2}$. In wet years the opposite should be the case due to higher soil $\mathrm{PCO}_{2}$ as a result of increased plant growth and root respiration.

Variations in reflectance across the cut stalagmite surface are affected by carbonate porosity, with dense, translucent calcite giving darker colors than lighter-colored, porous calcite. As denser calcite is normally deposited when there is a continuous layer of water over the top of the stalagmite (at Macal Chasm when rainfall was relatively high), darker colors usually record wetter intervals. However, this correlation is not perfect because dense translucent calcite and darker brown detritusrich calcite reflect little light but represent in the first case increased rainfall and in the second, reduced rainfall.

Luminescence in stalagmites is produced by organic acids and so is related to productivity in the soil and vegetation cover above the cave and can be expected to function as a proxy for availability of moisture. Luminescence varies inversely with grayscale reflectance, increasing in darker (translucent) carbonate and decreasing in lighter, more porous carbonate. The expected relationship of luminescence and moisture thus emerges, with dark, luminescent carbonate corresponding to wetter conditions and light and less luminescent carbonate correlating with drier conditions. Lighter colors derived from gray-level analysis coupled with lesser luminescence and increased $\delta^{18} \mathrm{O}$ and $\delta^{13} \mathrm{C}$ are indicative of drier and possibly cooler conditions.

There is a good but not perfect correlation between the proxy records from the stalagmite, one reason being that the data have different spatial/temporal resolutions (Figure 13). Luminescence and reflectance have a spatial resolution of $\sim .18 \mathrm{~mm}$, whereas the isotope data are spaced at 5-mm intervals and have a sample resolution of $2 \mathrm{~mm}$ (the diameter of the drill bit). As gray color and luminescence have a very high resolution, they are better choices than the stable isotopes for comparison with Maya history. In fact, luminescence is a better measure of wetness than reflectance because of low luminescence in porous (dry) carbonate and in zones of detrital clay, both indicating dry conditions. By comparison, high reflectance of porous calcite is an indicator of dryness, but low reflectance of detrital layers would normally suggest wetter conditions rather than the drier conditions that prevailed. Because of the sharp peaks and higher resolution of the luminescence data and the lack of ambiguity in their interpretation, luminescence was the record selected to estimate the timing of wet and dry intervals on the Vaca Plateau (Figure 13B).

An important aspect of the luminescence record is that many of the climate changes it records, particularly droughts, may have begun suddenly and ended abruptly. But it is possible that the speed of climate change affected the Maya as much as the magnitude of change. The luminescence record, which we think to be a proxy of rainfall, indicates that there was a significant dry period during the Late Preclassic around A.D. 141, which corresponds closely with the period of Preclassic abandonment from A.D. 150 to 200 . The luminescence data suggest that rainfall was more than one standard deviation below the 3,300-year mean for 15 years and more than one-half of a standard deviation below the mean for 37 years. The Preclassic abandonment was followed during the Early Classic period by a lengthy wet period from A.D. 250 


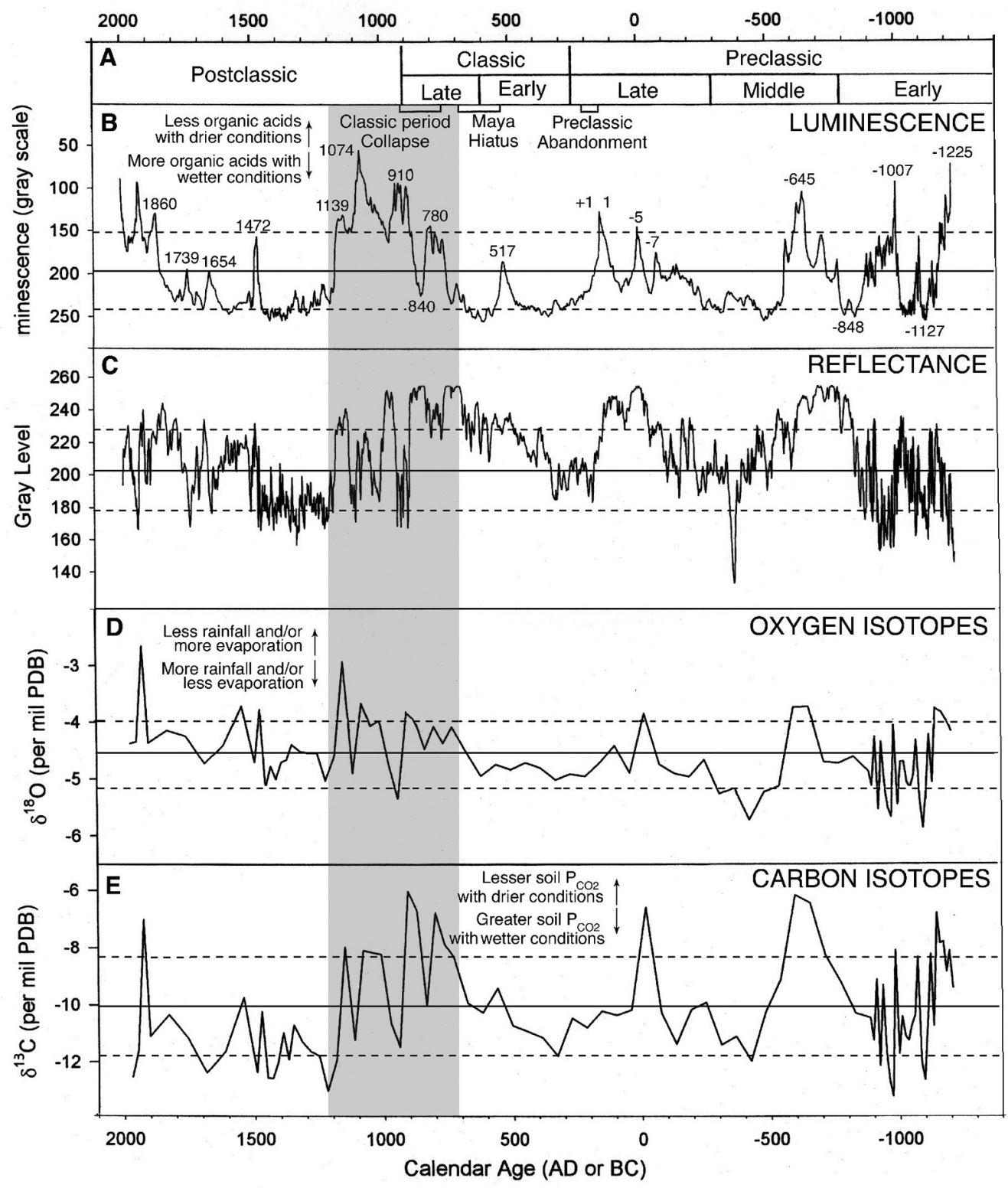

Figure 13. Luminescence, reflectance and stable isotope records from a Macal Chasm stalagmite compared with Maya cultural periods. The four records are plotted so that interpreted indicators of drier conditions are upward and indicators of wetter conditions are downward. Long term means of each variable are shown as a solid line and plus and minus one standard deviation values as dashed lines (modified after Webster et al. 2007).

to 600, when rainfall was at least one standard deviation above the mean. However, a minor dry interval during the later part of the Early Classic from ca. A.D. 490 to 580, with a peak around A.D. 517, appears to correspond with the Maya hiatus, which lasted from about A.D. 535 to 593. The luminescence record suggests that rainfall was at or very slightly below the long-term average for 17 years, tentatively suggesting that Maya agriculture may have been susceptible to even minor reductions in rainfall.

The wet conditions of the Early Classic and first half of the Late Classic period, interrupted only by the brief dry period around A.D. 517, gave way to 
a series of dry periods centered at about A.D. 780, 910,1074 , and 1139 . High $\delta^{18} \mathrm{O}$ values combine with minima in luminescence to suggest that these were the most extreme dry conditions in the entire 3,300-year record from the stalagmite. The first two peaks coincided with the Classic collapse of the ninth century. The Belize stalagmite shows peak dry conditions at A.D. 754-798, 871, and 893-922, with each successively increasing in severity. During the A.D. 780 peak, rainfall was half a standard deviation below the average for seven decades. The A.D. 910 peak was much more severe, with rainfall one standard deviation below average for 74 years and at least one and one-half standard deviations below average for 61 years. These dry periods coincide roughly with the three stages of abandonment ending in A.D. 810, 860, and 910 identified by Richardson Gill (2000). The dates from the stalagmite also correlate well with the termination occurring at approximately A.D. 850 of the two surface sites nearest Chechem Ha, Las Ruinas de Arenal (Taschek and Ball 1999) and Minanhá (Iannone 2001, 2005).

The long duration of the A.D. 780 and 910 droughts provides a likely reason why the Lowland Maya kingship never recovered and why people never fully reoccupied most urban centers in the area. Additionally, these were followed by the worst drought of all, occurring about A.D. 1074, when rainfall was one standard deviation below normal for 135 years, more than one and one half standard deviations below normal for 89 years and more than two standard deviations below normal for 24 years. Any attempt to recover would have ended abruptly under the harshness of such a prolonged and intense era of dry conditions (Figure 13B).

The beginning of the Late Classic dry cycle demonstrated in the Belize stalagmite coincides with changes in ritual practice at Chechem Ha Cave that commenced after A.D. 680. Additionally, almost all of the Late Classic ceramic vessels in the cave date to the Spanish Lookout phase dating from A.D. 700 to 900 . A ritual response to the drier conditions would be expected to have occurred during the decline in rainfall beginning about A.D. 700 or as a response to the first peak in dryness at about A.D. 780. Although the cave may have been used as late as A.D. 960, it is likely to have been closed off as early as A.D. 850, coinciding with the termination of local surface sites. While we are aware that correlation does not equal causation, the timing of changes in ritual practice in the cave and the beginning of the drying trend are simultaneous in archaeological time scales. Although our temporal data are never as fine grained as we might like, the nature of the Late Classic ceramic assemblage also supports our argument.

During the Late Classic period ceramic counts increase and consist of more numerous complete or partially intact vessels, most of which are large jars. These jars represent elaborated offerings as compared with the fragmentary nature of earlier deposits. As discussed above, jars in caves are most likely references to rain poured from the sky and are appropriate votive offerings for rain deities. An increase in the overall number of vessels and change in their conditions suggest that these deities are given special treatment at this time.

Additionally, the presence of the central Mexican rain deity becomes prevalent in Belize in the Late to Terminal Classic period. Awe has noted the increasing presence of Tlaloc imagery both at surface sites and in cave contexts. For example, the Terminal Classic construction phase at Temple B5 at Caracol is decorated with Tlaloc masks flanking the central stairway. On the same building Reiko Ishihara and her colleagues (2006) have argued that stucco facades depicting the Water Lily Serpent found on the Late Classic penultimate construction phase identify them as water temples. Also dating to the Late or Terminal Classic period is a carved slate slab decorated with Tlaloc imagery discovered at Actun Tunichil Muknal (Awe et al. 2005). This Late Classic manifestation of Tlaloc motifs is also found on censers as far north as Yucatán, most notably at Balankanche Cave (Andrews 1970).

\section{The Late Classic Drought Cult}

Given the deep antiquity of Maya beliefs that associate caves with gods that control water, at a time of environmental crisis, caves would have been an appropriate ritual venue to appease or win favor with these deities. While rain rites may always have been part of cave ritual, in the Late Classic period major changes occurred in the way that rituals were conducted. This is evident in the preferential use of elevated and esoteric areas of the cave and in the elaboration of ritual assemblages. The deposition of intact or partially intact jars in caves as the focus 
of cave ritual in the Late Classic further suggests the propitiation of these deities.

At Chechem Ha Cave the phenomena can be temporally circumscribed beginning sometime after A.D. 680 and ending before A.D. 960, coincident with the abandonment of local surface sites. The correlation between the changes in practice and the onset of a prolonged dry period can hardly be accidental. It is also interesting to note that it is not until the latter part of the Late Classic period, concurrent with climatic drying, that evidence for first fruit rites occurred within the site. This is intriguing when we consider the work of Freidel and Shaw (2000), which suggests that these types of rites are most often coincident with risky environments.

These data suggest that a Late Classic drought cult was initiated during the earlier stages of the prolonged dry era. Although this study confines itself to Belizean cave sites, the cult may extend to other areas of the Maya Lowlands. Ritual cults devoted to rain deities or other water-related manifestations may exist in other contexts, such as in iconography at surface sites or in depictions in portable art. These Late Classic manifestations may be indicative of a widespread movement of which cave rites are only one facet, albeit an important one.

\section{Conclusion}

When we consider the relationship among caves, water control, and agricultural fertility, it is hardly surprising that caves should become the focus of specialized ritual during a time of climatic stress. This information is important in understanding how the dry period affected the lives of Maya people. Data from caves in Belize support that there was a ritual response to the environmental phenomena recorded in paleoclimate records. The existence of this response indicates that for the ancient Maya people, the period of climatic drying was not an abstract concept but, rather, a perceived problem. It provides indirect evidence to suggest that in reality crops were failing and that ritual technology was used to mitigate the situation.

The temporal span of the Late Classic drought cult at Chechem Ha is also informative because it was initiated in the early part of the drying trend and ended at approximately the same time as the elite structures in the surrounding surface sites were terminated. Recall that the cave entrance was blocked after its final use, never to be reopened by the ancient users-even in the Postclassic period when there were known populations at two of the nearest surface sites, Minanhá (Iannone 2005:37) and Tipu (Aimers 2004). Therefore, the initial increase of ritual activity in the Late Classic period followed by a cessation of rites may be construed as a ritual failure. The changes in practice within Belizean cave sites provide some of the first direct archaeological evidence to demonstrate that loss of faith played a significant role in the political collapse of the ancient Lowland Maya.

Acknowledgments. We would like to thank members of the Belize Institute of Archaeology including John Morris, George Thompson, and Brian Woodeye. Moyes and Awe extend appreciation to the Morales and Plytez families as well as crew members Jim Aimers, Anthony Beardsall, Jim Conlon, Jennifer Ehret, Cameron Griffith, Christophe Helmke, Reiko Ishihara, Mike Mirro, Grant Polley, Connie Price, Kay Sunahara, and Myka Schwanke. Mark Aldenderfer provided computer equipment for the project, and Nathan Craig was instrumental in implementing the photomapping technique. Thanks go to Joseph Ball and Jennifer Taschek for identifying problematic ceramics. This article benefited from critical comments by Lisa Lucero, Keith Prufer, Michael Schiffer, Vernon Scarborough, and an anonymous reviewer. Various aspects of the project were funded by a National Science Foundation (NSF) dissertation improvement grant (BCS0315303) to Moyes and Ezra Zubrow, the Foundation for the Advancement of Mesoamerican Studies, Inc., the Cave and Karst Conservancy, the Cave Research Foundation, and the Mark Diamond fund at the University at Buffalo. Early work was funded by a grant to Awe from the Social Science Research Council of Canada. Research on the Macal Chasm stalagmite was supported by NSF grants 9628765 and 9908415 to James Webster and by a grant from the Geological Society of America.

\section{References Cited}

Aimers, J. James

2004 Cultural Change on a Temporal and Spatial Frontier: Ceramics of the Terminal Classic to Postclassic Transition in the Upper Belize River Valley. Archaeopress, Oxford.

2007 What Maya Collapse? Terminal Classic Variation in the Maya Lowlands. Journal of Archaeological Research 15:329-377.

Aldenderfer, Mark S., and Nathan Craig

2002 A GIS-Based In-Field Data Recording System for Archaeological Excavation. Paper presented at the 13th Annual Workshops in Archaeometry, University at Buffalo.

Andrews, E. Wyllys, IV

1965 Explorations in the Gruta de Chac Yucatan, Mexico. Middle American Research Institute, Tulane University, New Orleans. 
1970 Balankanche, Throne of the Tiger Priest. Middle American Research Institute, Publication 32. Tulane University, New Orleans.

Ashmore, Wendy, Sam V. Connell, Jennifer J. Ehret, Clarence H. Gifford, L. Theodore Neff, and Jon C. Vandenbosch

1994 The Xunantunich Settlement Survey. In Xunantunich Archaeological Project: 1994 Field Season. On file at the Belize Institute of Archaeology, Belmopan.

Awe, Jaime J.

1985 Archaeology Investigations at Caledonia, Cayo District, Belize. Unpublished Master's thesis, Department of Anthropology, Trent University.

1992 Dawn in the Land Between the Rivers: Formative Occupation at Cahal Pech, Belize and Its Implications for Preclassic Development in the Maya Lowlands. Unpublished Ph.D. dissertation, Department of Archaeology, University of London.

Awe, Jaime J., Sherry Gibbs, and Cameron Griffith

2005 Stelae and Megalithic Monuments in the Caves of Western Belize. In In the Maw of the Earth Monster: Mesoamerican Ritual Cave Use, edited by James E. Brady and Keith M. Prufer, pp. 223-248. University of Texas Press, Austin.

Balme, Jane, and Wendy E. Beck

2002 Starch and Charcoal: Useful Measures of Activity Areas in Archaeological Rockshelters. Journal of Archaeological Science 29:157-166.

Bell, Catherine

1997 Ritual: Perspectives and Dimensions. Oxford University Press, New York.

Binford, Lewis R.

1968 Methodological Considerations of the Archaeological Use of Ethnographic Data. In Man the Hunter, edited by R. Lee and I. Devore, pp. 268-273. Aldine, Chicago.

Brady, James E.

1989 Investigation of Maya Ritual Cave Use with Special Reference to Naj Tunich, Peten, Guatemala. Unpublished Ph.D. dissertation, Department of Anthropology, University of California, Los Angeles.

Brady, James E., and Wendy Ashmore

1999 Mountains, Caves, Water: Ideational Landscapes of the Ancient Maya. In Archaeologies of Landscapes: Contemporary Perspectives, edited by Wendy Ashmore and A. Bernard Knapp, pp. 124-145. Blackwell Publishers, Oxford.

Brady, James E., and Pierre R. Colas

2005 Nikte Mo' Scattered Fire in the Cave of K'ab Chante: Epigraphic and Archaeological Evidence for Cave Desecration in Ancient Maya Warfare. In Stone Houses and Earth Lords: Maya Religion in the Cave Context, edited by Keith M. Prufer and James E. Brady, pp. 149-166. University Press of Colorado, Boulder.

Brady, James E., and Keith Prufer

2005 Maya Cave Archaeology: A New Look at Religion and Cosmology. In Stone Houses and Earth Lords: Maya Religion in the Cave Context, edited by Keith M. Prufer and James E. Brady, pp. 365-380. University Press of Colorado, Boulder.

Brenner, Mark, Michael F. Rosenmeier, David A. Hodell, and Jason H. Curtis

2002 Paleolimnology of the Maya Lowlands: Long-Term Perspectives on Interactions Among Climate, Environment, and Humans. Ancient Mesoamerica 13:141-157.

Brook, George A

1999 Arid Zone Paleoenvironmental Records from Cave Speleothems. In Paleoenvironmental Reconstruction in Arid Lands, edited by A. K. Singhvi and E. Derbyshire, pp. 217-262. Oxford and IBH Publishing Co. Pvt. Ltd., New Delhi.

Coe, Michael

1978 Lords of the Underworld. Princeton University Press, Princeton.

Colas, Pierre Robert

1998 Ritual and Politics in the Underworld. Mexicon 20(5):99-104.

Craig, Nathan

2000 Real-Time GIS Construction and Digital Data Recording of the Jiskairumoko Excavation, Peru. Society for American Archaeology Bulletin 18(1):24-28.

Craig, Nathan, Mark Aldenderfer, and Holley Moyes

2006 Multivariate Visualization and Analysis of Photomapped Artifact Scatters. Journal of Archaeological Science 20:1-10.

Curtis, Jason H., Mark Brenner, David A. Hodell, Richard A. Balser, Gerald A. Islebe, and Henry Hooghiemstra

1998 A Multi-Proxy Study of Holocene Environmental Change in the Maya Lowlands of Peten, Guatemala. Journal of Paleolimnology 19:139-159.

Curtis, Jason H., David A. Hodell, and Mark Brenner

1996 Climate Variability on the Yucatan Peninsula (Mexico) During the Past 3500 Years, and Implications for Maya Cultural Evolution. Quaternary Research 46:37-47.

Demarest, Arthur A., Prudence M. Rice, and Don S. Rice

2004 The Terminal Classic in the Maya Lowlands: Assessing Collapse, Transition, and Transformation. In The Terminal Classic in the Maya Lowlands: Collapse, Transition, and Transformation, edited by Arthur A. Demarest, Prudence M. Rice, and Don S. Rice, pp. 545-572. University Press of Colorado, Boulder.

Dunning, Nicholas P., David Rue, Timothy Beach, Alan Covich, and Alfred Traverse

1997 Human-Environmental Interactions in a Tropical Watershed: The Paleoecology of Laguna Tamarindito, El Petén, Guatemala. Journal of Field Archaeology 25:139-151.

Durán, Fray Diego

1971 [1588] Book of the Gods and Rites and the Ancient Calendar. Translated by Doris Heyden and Miguel LeonPortilla. University of Oklahoma Press, Norman.

Ford, Derek C., and P. W. Williams

1989 Karst Geomorphology and Hydrology. Unwin Hyman, Boston.

Freidel, David

1981 Civilization as a State of Mind: The Cultural Evolution of the Lowland Maya. In The Transition to Statehood in the New World, edited by Grant D. Jones and Robert R. Kautz, pp. 188-227. Cambridge University Press, New York.

Freidel, David, and Justine Shaw

2000 The Lowland Maya Civilization: Historical Consciousness and Environment. In The Way the Wind Blows: Climate, History, and Human Action, edited by Roderick J. McIntosh, Joseph A. Tainter, and Susan Keech McIntosh, pp. 271-300. Columbia University Press, New York. Gann, Thomas

1925 Mystery Cities: Exploration andAdventure in Lubaantun. Duckworth, London.

Garber, James F., M. Kathryn Brown, Jaime J. Awe, and Christopher J. Hartman

2004 Middle Formative Prehistory of the Central Belize Valley: An Examination of Architecture, Material Culture, and Sociopolitical Change at Blackman Eddy. In The Ancient Maya of the Belize Valley: Half a Century of Archaeological Research, edited by James F. Garber, pp. 
25-48. University Press of Florida, Gainesville.

Gifford, James C.

1976 Prehistoric Pottery Analysis and the Ceramics of Barton Ramie in the Belize Valley. Compiled by Carol A. Gifford. Memoirs of the Peabody Museum of Archaeology and Ethnology 18. Harvard University, Cambridge.

Gill, Richardson B.

2000 The Great Maya Droughts: Water, Life, and Death. University of New Mexico Press, Albuquerque.

Girard, Raphael

1995 People of the Chan. Translated by Bennett Preble. Continuum Foundation, Chino Valley, Arizona. Originally published 1966.

Gossen, Gary H.

1999 Telling Maya Tales: Tzotzil Identities in Modern Mexico. Routledge, New York.

Graham, Elizabeth, Logan McNatt, and Mark A. Gutchen

1980 Excavations in Footprint Cave, Belize. Journal of Field Archaeology 7:153-172.

Graham, Ian

1997 Discovery of a Maya Ritual Cave in Peten, Guatemala. Symbols, Spring:28-31.

Grove, David C., and Susan Gillespie

1984 Chalcatzingo's Portrait Figurines and the Cult of the Ruler. Archaeology 37(4):27-33.

Haug, Gerald H., Detlef Gunther, and Larry C. Peterson

2003 Climate and the Collapse of the Maya Civilization. Science 299:1731-1735.

Haviland, William A., Harald E. L. Prins, Dana Walrath, and Bunny McBride

2005 Cultural Anthropology: The Human Challenge. 11th ed. Wadsworth, USA.

Helmke, Christophe G. B.

1999 Exploration and Investigations of the Sinkhole Tunnels, Actun Tunichil Muknal, Belize. In The Western Belize Regional Cave Project: A Report of the 1998 Field Season, edited by Jaime J. Awe, pp. 146-165, Department of Anthropology Occasional Paper No. 2. University of New Hampshire, Durham.

2005 The Terminal Classic: Molded-Carved Ceramic Tradition of the Eastern Maya Lowlands. Paper presented at the 70th Annual Meeting of the Society for American Archaeology, Salt Lake City.

Helmke, Christophe G. B., Cameron S. Griffith, and Michael J. Mirro

1999 The 1996 and 1998 Investigations at Laberinto de las Tarantuals, Cayo District, Belize. In The Western Belize Regional Cave Project: A Report of the 1998 Field Season, edited by Jaime J. Awe, pp. 205-221. Department of Anthropology, Occasional Paper No. 2. University of New Hampshire, Durham.

Hendy, Chris H.

1971 The Isotopic Geochemistry of Speleothems I. The Calculation of Different Modes of Formation on the Isotope Composition of Speleothems and Their Applicability as Palaeoclimate Indicators. Geochimica et Cosmochimica Acta 35:801-824.

Hill, Carol A., and Paolo Forti

1997 Cave Minerals of the World. 2nd ed. National Speleological Society, Huntsville, Alabama. Originally published 1986.

Hodell, David A., Jason H. Curtis, and Mark Brenner

1995 Possible Role of Climate in the Collapse of the Classic Maya Civilization. Nature 375:391-394.

Hodell, David A., Jason H. Curtis, Mark Brenner, and Thomas P. Guilderson

2001 Solar Forcing of Drought Frequency in the Maya
Lowlands. Science 292:1367-1370.

Hosler, D., Jeremy Sabloff, and D. Runge

1977 Simulation Model Development: A Case Study of the Classic Maya Collapse. In Social Processes in Maya Prehistory, edited by Norman Hammond, pp. 553-590. Academic Press, London.

Iannone, Gyles

2001 Fall of the House of Minanhá: A Case of Late Classic Political Disruption in West Central Belize. In Archaeological Investigations in the North Vaca Plateau, Belize: Progress Report of the Third (2001) Field Season, edited by Gyles Iannone, Ryan Primrose, Adam Menzies, and Lisa McParland, pp. 127-133. Department of Anthropology, Trent University, Peterborough, Ontario.

2005 The Rise and Fall of the House of an Ancient Maya Petty Royal Court. Latin American Antiquity 16(1):26-44.

Ishihara, Reiko, Karl A. Taube, and Jaime J. Awe

2006 The Water Lily Serpent Stucco Masks at Caracol, Belize. Research Reports in Belizean Archaeology 3:213-224

Krickeberg, W.

1975 Las antiguas culturas mexicanas. Fondo de Cultura Económica, Mexico City.

Lopiparo, Jane

2001 "Fractious Statelets" and "Galactic Polities": Ideology, Ritual Practices and the Rise and Fall of Classic Maya States. In Past Ritual and the Everyday, edited by Christine A. Hastorf, pp. 49-66. Kroeber Anthropological Society Papers, No. 85. University of California, Department of Anthropology, Berkeley.

Lowe, John W. G.

1985 The Dynamics of Apocalypse: A Systems Simulation of the Classic Maya Collapse. University of New Mexico Press, Albuquerque.

Lucero, Lisa J.

2002 The Collapse of the Classic Maya: A Case for the Role of Water Control. American Anthropologist 104(3):814-826.

2006 Water and Ritual: The Rise and Fall of Classic Maya Rulers. University of Texas Press, Austin.

Luján, Leonardo López

1998 Re-Creating the Cosmos: Seventeen Aztec Dedication Caches. In The Sowing and the Dawning: Termination, Dedication, and Transformation in the Archaeological Record of Mesoamerica, edited by Shirley B. Mock, pp. 177-188. University of New Mexico Press, Albuquerque.

Malinowski, Bronislaw K.

1954 Magic, Science, and Religion. Doubleday, Garden City, N.Y.

Marcus, Joyce A.

2006 The Roles of Ritual and Technology in Mesoamerican Water Management. In Water Management and Agricultural Strategies, edited by Joyce A. Marcus and Charles Stanish, pp. 221-254. Cotsen Institute of Archaeology, University of California, Los Angeles.

Marcus, Joyce A., and Kent V. Flannery

1994 Ancient Zapotec Ritual and Religion: An Application of the Direct Historical Approach. In The Ancient Mind, edited by A. Colin Renfrew and Ezra B. W. Zubrow, pp. 55-74. Cambridge University Press, Cambridge.

McAnany, Patricia A., Kimberly A. Berry, and Ben S. Thomas 2003 Wetlands, Rivers, and Caves: Agricultural and Ritual Practice in Two Lowland Maya Landscapes. In Perspectives on Ancient Maya Rural Complexity, edited by Gyles Iannone and Samuel V. Connell, pp. 71-82. Monograph 49. Cotsen Institute of Archaeology, University of California, Los Angeles. 
Miller, Mary Ellen

1993 On the Eve of the Collapse: Maya Art of the Eighth Century. In Lowland Maya Civilization in the 8th Century A.D., edited by Jeremy A. Sabloff and John S. Henderson, pp. 355-414. Dumbarton Oaks, Washington, D.C.

Miller, Thomas

1989 Tunichil Muknal. Caves and Caving 46:2-7.

1990 National Speleological Society News 48(2):32-35.

Mirro, Michael, and Vanessa Mirro

2001 A Report of the 2000 Field Season at the Barton Creek Cave, Cayo District, Belize. In The Western Belize Regional Cave Project: A Report of the 2000 Field Season, edited by Reiko Ishihara, Cameron Griffith, and Jaime J. Awe, pp. 97-126. Department of Anthropology, Occasional Paper No. 4. University of New Hampshire, Durham.

Morehart, Christopher T.

2002 Ancient Maya Ritual Cave Utilization: A Paleoethnobotanical Perspective. Unpublished Master's thesis, Department of Anthropology, Florida State University.

2005 Plants and Caves in Ancient Maya Society. In Stone Houses and Earth Lords: Maya Religion in the Cave Context, edited by Keith M. Prufer and James E. Brady, pp. 167-186. University Press of Colorado, Boulder.

Morehart, Christopher T., Jaime J. Awe, Michael Mirro, Vanessa Owen, and Christophe G. B. Helmke

2004 Ancient Textile Remains from Barton Creek Cave, Cayo District, Belize. Mexicon 26(3):50-56.

Morehart, Christopher T., David L. Lentz, and Keith M. Prufer 2005 Wood of the Gods: The Ritual Use of Pine (Pinus spp.) by the Ancient Lowland Maya. Latin American Antiquity $16: 255-274$

Moyes, Holley

2001 The Cave as a Cosmogram: The Use of GIS in an Intrasite Spatial Analysis of the Main Chamber of Actun Tunichil Muknal, a Maya Ceremonial Cave in Western Belize. Unpublished Master's thesis, Florida Atlantic University, Boca Raton.

2002 The Use of GIS in the Spatial Analysis of an Archaeological Cave Site. Journal of Cave and Karst Studies 64(1):9-16.

2004 Changes and Continuities in Ritual Practice at Chechem Ha Cave, Belize: Report on Excavations Conducted in the 2003 Field Season. Report submitted to the Foundation for the Advancement of Mesoamerican Studies, Inc., http://www.famsi.org/reports.

2005a Cluster Concentrations, Boundary Markers, and Ritual Pathways: A GIS Analysis of Artifact Cluster Patterns at Actun Tunichil Muknal, Belize. In In the Maw of the Earth Monster: Studies of Mesoamerican Ritual Cave Use, edited by James Brady and Keith Prufer, pp. 269-300. University of Texas Press, Austin.

2005b The Sweatbath in the Cave: A Modified Passage in Chechem Ha Cave, Belize. In Stone Houses and Earth Lords: Maya Religion in the Cave Context, edited by Keith M. Prufer and James E. Brady, pp. 187-212. University Press of Colorado, Boulder.

2006a The Sacred Landscape as a Political Resource: A Case Study of Ancient Maya Cave Use at Chechem Ha Cave, Belize, Central America. Unpublished Ph.D. dissertation, Department of Anthropology, State University of New York at Buffalo.

2006b The Archaeology of Chechem Ha Cave, Belize: A Late Classic Hiatus in Usage. Research Reports in Belizean Archaeology 3:225-234.

2007 The Late Classic Drought Cult: Ritual Activity as a Response to Environmental Stress Among the Ancient Maya. In Cult in Context: Reconsidering Ritual in Archae- ology, edited by David Barrowclough and Caroline Malone, pp. 217-228. Oxbow Books, Oxford.

2008 Charcoal as a Proxy for Use-Intensity in Ancient Maya Cave Ritual. In Religion in the Material World, edited by Lars Fogelin, pp. 139-158. Center for Archaeological Investigations, Carbondale, Illinois.

Moyes, Holley, and Jaime J. Awe

1998 Spatial Analysis of Artifacts in the Main Chamber of Actun Tunichil Muknal, Belize: Preliminary Results. In The Western Belize Regional Cave Project: A Report of the 1997 Field Season, edited by Jaime J. Awe, pp. 23-36. Department of Anthropology, Occasional Paper No. 1. University of New Hampshire, Durham.

2000 Spatial Analysis of an Ancient Cave Site. ArcUser 3(4):64-68.

Moyes, Holley, Jaime J. Awe, and Henry Schwarcz

2006 Tracing the Origin of Speleothems at Ancient Maya Archaeological Sites in Belize, Central America. Report on file with the Institute of Archaeology, National Institute of Culture and History, Belmopan.

Moyes, Holley, and James E. Brady

2005 The Heart of Heaven, the Heart of Darkness: Ritual Cave Use in Mesoamerica. Expedition 47(3):30-36.

Nash, June

1970 In the Eyes of the Ancestors: Belief and Behavior in a Maya Community. Yale University Press, New Haven.

Ortner, Sherry B.

1989 High Religion: A Cultural and Political History of Sherpa Buddhism. Princeton University Press, Princeton. Owen, Vanessa A., and Sherry Gibbs

1999 Report of Investigations on Ledge 2 at Actun Yaxteel Ahau, Roaring Creek Valley, Belize. In The Western Belize Regional Cave Project: A Report of the 1998 Field Season, edited by Jaime J. Awe, pp. 186-204. Department of Anthropology, Occasional Paper No. 2. University of New Hampshire, Durham.

Palacio, Joseph

1977 Excavations at Hokeb Ha, Belize. Belize Institute for Social Research and Action Occasional Publication 3. Belize City.

Pendergast, David M.

1969 The Prehistory of Actun Balam, British Honduras. Art and Archaeology Occasional Papers 16. Royal Ontario Museum, Toronto.

1970 A. H. Anderson's Excavations at Rio Frio Cave E, British Honduras. Art and Archaeology Occasional Papers 20. Royal Ontario Museum, Toronto.

1971 Excavations at Eduardo Quiroz Cave, British Honduras (Belize). Royal Ontario Museum Art and Archaeology Occasional Paper 21. Royal Ontario Museum, Toronto. 1974 Excavations at Actun Polbiche, Belize. Archaeology Monograph 1. Royal Ontario Museum, Toronto.

Peterson, Larry, and Gerald H. Haug

2005 Climate and the Collapse of Maya Civilization. American Scientist 93:322-329.

Phillips, Henry

1844 Notes Upon the Codex Ramirez, with a Translation of the Same. Proceedings of the American Philosophical Society 21(116):616-651.

Prufer, Keith M.

2002 Communities, Caves, and Ritual Specialists: A Study of Sacred Space in the Maya Mountains of Southern Belize. Unpublished Ph.D. dissertation, Southern Illinois University, Carbondale.

Puleston, Dennis E.

1979 An Epistemological Pathology and the Collapse, or Why the Maya Kept the Short Count. In Maya Archaeol- 
ogy and Ethnohistory, edited by Norman Hammond and Gordon R. Willey, pp. 63-74. University of Texas Press, Austin.

Rands, Robert L.

1955 Some Manifestations of Water in Mesoamerican Art. Anthropological Papers No. 48. Smithsonian Institution Bureau of American Ethnology Bulletin 157. Washington, D.C.

Rappaport, Roy A.

1979 Ecology, Meaning, and Religion. North Atlantic Books, Richmond, California.

Reents-Budet, Dorie Jane, and Barbara MacLeod

1997 The Archaeology of Petroglyph Cave, Cayo District, Belize. MS on file at the Belize Institute of Archaeology, Belmopan.

Reid, Jefferson J., Michael B. Schiffer, and William J. Rathje

1975 Behavioral Archaeology: Four Strategies. American Anthropologist 77:864-869.

Reilly, F. Kent, III

1994 Visions to Another World: Art, Shamanism, and Political Power in Middle Formative Mesoamerica. Ph.D. dissertation, Department of Art History, University of Texas, Austin.

Reina, Ruben E., and Robert M. Hill

1978 The Traditional Pottery of Guatemala. University of Texas Press, Austin.

Renfrew, A. Colin

1978 Trajectory Discontinuity and Morphogenesis: The Implications of Catastrophe Theory of Archaeology. American Antiquity 43:203-244.

Reents-Budet, Dorie Jane

1980 The Prehistoric Pottery from Petroglyph Cave, Caves Branch Valley, El Cayo District, Belize, Central America. Master's Thesis, University of Texas.

Rice, Prudence M.

2004 Maya Political Science: Time, Astronomy, and the Cosmos. University of Texas Press, Austin.

Rissolo, Dominique A.

2001 Ancient Maya Cave Use in the Yalahau Region, Northern Quintana Roo, Mexico. Unpublished Ph.D. dissertation, Department of Anthropology, University of California, Riverside.

2005 Beneath the Yalahau: Emerging Patterns of Ancient May Ritual Cave Use from Northern Quintana Roo, Mexico. In In the Maw of the Earth Monster: Mesoamerican Ritual Cave Use, edited by James E. Brady and Keith M. Prufer, pp. 342-372. University of Texas Press, Austin.

Robin, Cynthia, William D. Middleton, Santiago Juarez, and Mary K. Morrison

2004 Surveying an Agrarian Community: The 2002 Field Season at the Chan Site, Belize. Research Reports in Belizean Archaeology 1:38-48.

Rosen, Arlene M.

1993 Microartifacts as a Reflection of Cultural Factors in Site Formation. In Formation Processes in Archaeological Context, edited by Paul Goldberg, David T. Nash, and Michael Petraglia, pp. 141-148. Monographs in World Archaeology No. 17. Prehistory Press, Madison, Wiscon$\sin$.

Rosenmeier, Michael F., David A. Hodell, Mark Brenner, Jason H. Curtis, and Thomas P. Guilderson

2002 A 4,000-Year Lacustrine Record of Environmental Change in the Southern Maya Lowlands, Petén, Guatemala. Quaternary Research 57:183-190.

Sahagun, Bernardino de

1981 General History of the Things of New Spain, Book 2. Translated by A. J. O. Anderson and C. Dibble. Univer- sity of Utah Press, Salt Lake City.

Salamini, Leonardo

1981 The Sociology of Political Praxis: An Introduction to Gramsci's Theory. Routledge and Keegan Paul, Boston.

Sandstrom, Alan R.

2005 The Cave-Pyramid Complex Among the Contemporary Nahau of Northern Veracruz. In In the Maw of the Earth Monster: Mesoamerican Ritual Cave Use, edited by James E. Brady and Keith M. Prufer, pp. 35-68. University of Texas Press, Austin.

Saturno, William A., Karl A. Taube, David Stuart, and Heather Hurst

2005 The Murals of San Bartolo, El Petén, Guatemala, Part 1: The North Wall. Ancient America 7:1-56.

Scarborough, Vernon L.

1998 Ecology and Ritual: Water Management and the Maya. Latin American Antiquity 9:135-159.

2003 The Flow of Power: Ancient Water Systems and Landscapes. School of American Research Press, Santa Fe.

Schiffer, Michael B.

1987 Formation Processes of the Archaeological Record. University of New Mexico Press, Albuquerque.

1995 Behavioral Archaeology: First Principles. University of Utah Press, Salt Lake City.

1996 Some Relationships Between Behavioral and Evolutionary Archaeologies. American Antiquity 61:643-662. 1999 Behavioral Archaeology: Some Clarifications. American Antiquity 64:166-168.

Schwarcz, Henry P., and W. J. Rink

2001 Dating Methods for Sediments of Caves and Rockshelters with Examples from the Mediterranean Region. Geoarchaeology 16(4):355-371.

Seler, Eduard

1991 [1902-1923] Collected Works in Mesoamerican Linguistics and Archaeology. Labyrinthos, Culver City.

Smith, Pierre

1982 Aspects of the Organization of Rites. In Between Belief and Transgression: Structuralist Essays in Religion, History, and Myth, edited by Michel Izard and Pierre Smith, pp. 103-128. University of Chicago Press, Chicago.

Smyth, Michael P.

1998 A New Study of the Gruta de Chac, Yucatán, México. Submitted to the Foundation for the Advancement of Mesoamerica Studies, Inc., http://www.famsi.org/ reports/97011.

Stone, Andrea J.

1995 Images from the Underworld: Naj Tunich and the Tradition of Maya Cave Painting. University of Texas Press, Austin.

2005 Scribes and Caves in the Maya Lowlands. In Stone Houses and Earth Lords: Maya Religion in the Cave Context, edited by Keith M. Prufer and James E. Brady, pp. 135-147. University Press of Colorado, Boulder.

Tarn, Nathaniel, and Martin Prechtel

1986 Constant Inconstancy: The Feminine Principle in Atiteco Mythology. In Symbol and Meaning Beyond the Closed Community: Essays in Mesoamerican Ideas, edited by Gary Gossen, pp. 173-184. Institute for Mesoamerican Studies, University at Albany, State University of New York, Albany.

Taschek, Jennifer T., and Joseph W. Ball

1999 Las Ruinas de Arenal: Preliminary Report on a Subregional Major Center in the Western Belize Valley (1991-1992 Excavations). Ancient Mesoamerica 10:215-235.

Taube, Karl A.

1992 The Major Gods of Ancient Yucatan. Dumbarton Oaks, 
Washington, D.C.

1995 The Legendary Past: Aztec and Maya Myths. University of Texas Press, Austin.

Theunissen, Robert, Jane Balme, and Wendy E. Beck

1998 Headroom and Human Trampling: Cave CeilingHeight Determines the Spatial Patterning of Stone Artefacts at Petzkes Cave, Northern New South Wales. Antiquity 72(275):80-89.

Thompson, J. Eric

1954 The Rise and Fall of the Maya Civilization. University of Oklahoma Press, Norman.

Thompson, Raymond $\mathrm{H}$.

1958 Modern Yucatecan Maya Pottery Making. Memoirs of the Society for American Archaeology, Vol. 23(4), Part 2. Salt Lake City.

U.N. Land and Water Development Division

2007 February 2. Electronic document, http://www.fao.org/ $\mathrm{ag} / \mathrm{agl} / \mathrm{aglw} / \mathrm{aquastat} / \mathrm{countries/belize/index.stm.}$

Van Gennep, Arnold

1960 The Rites of Passage. University of Chicago Press, Chicago.

Villacorta, J. Antonio

1992 The Dresden Codex: Drawings of the Pages. Mayan Studies No. 3. Aegean Park Press, Walnut Creek, California.

Vogt, Evon Z.

1965 Structural and Conceptual Replication in Zinacantan Culture. In Reader in Comparative Religion: An Anthropological Approach, 2nd ed., edited by William Lessa and Evon Vogt, pp. 602-609. Harper and Row, New York.

Walker, William H.

1995 Ceremonial Trash? In Expanding Archaeology, edited by James M. Skibo, William H. Walker, and Axel E. Nielsen, pp. 67-79. University of Utah Press, Salt Lake City.

Webb, Malcolm C.

1973 The Peten Maya Decline Viewed in the Perspective of State Formation. In The Classic Maya Collapse, edited by T. Patrick Culbert, pp. 367-391. University of New Mexico Press, Albuquerque.
Webster, David L.

2002 The Fall of the Ancient Maya: Solving the Mystery of the Maya Collapse. Thames and Hudson, London.

Webster, James W.

2000 Speleothem Evidence of Late Holocene Climate Variation in the Maya Lowlands of Belize Central America and Archaeological Implications. Unpublished Ph.D. dissertation, Department of Geology, University of Georgia, Athens.

Webster, James W., George A. Brook, L. Bruce Railsback, Hai Cheng, R. Lawrence Edwards, Clark Alexander, and Philip P. Reeder

2007 Stalagmite Evidence from Belize Indicating Significant Droughts at the Time of Preclassic Abandonment, the Maya Hiatus, and the Classic Maya Collapse. Palaeogeography, Palaeoclimatology, Palaeoecology 250:1-17.

Whitehouse, Harvey

2004 Modes of Religiosity: A Cognitive Theory of Religious Transmission. AltaMira Press, New York.

Willey, Gordon R., and Demitri B. Shimkin

1971 Why Did the Pre-Columbian Maya Civilization Collapse? Science 173:656-658.

1973 The Maya Collapse: A Summary View. In The Classic Maya Collapse, edited by Patrick T. Culbert, pp. 457-501. University of New Mexico Press, Albuquerque.

Woodfill, Brent Kerry Skoy

2007 Shrines of the Pasión-Verapaz Region, Guatemala: Ritual and Exchange along an Ancient Trade Route. Unpublished Ph.D. dissertation, Department of Anthropology, Vanderbilt University, Nashville.

Zantwijk, R. van

1981 The Great Temple of Tenochtitlán: Model of Aztec Cosmovision. In Mesoamerican Sites and World-Views, edited by Elizabeth P. Benson, pp. 71-86. Dumbarton Oaks, Washington, D.C.

Submitted June 22, 2007; Accepted October 2, 2007; Revised May 3, 2008. 